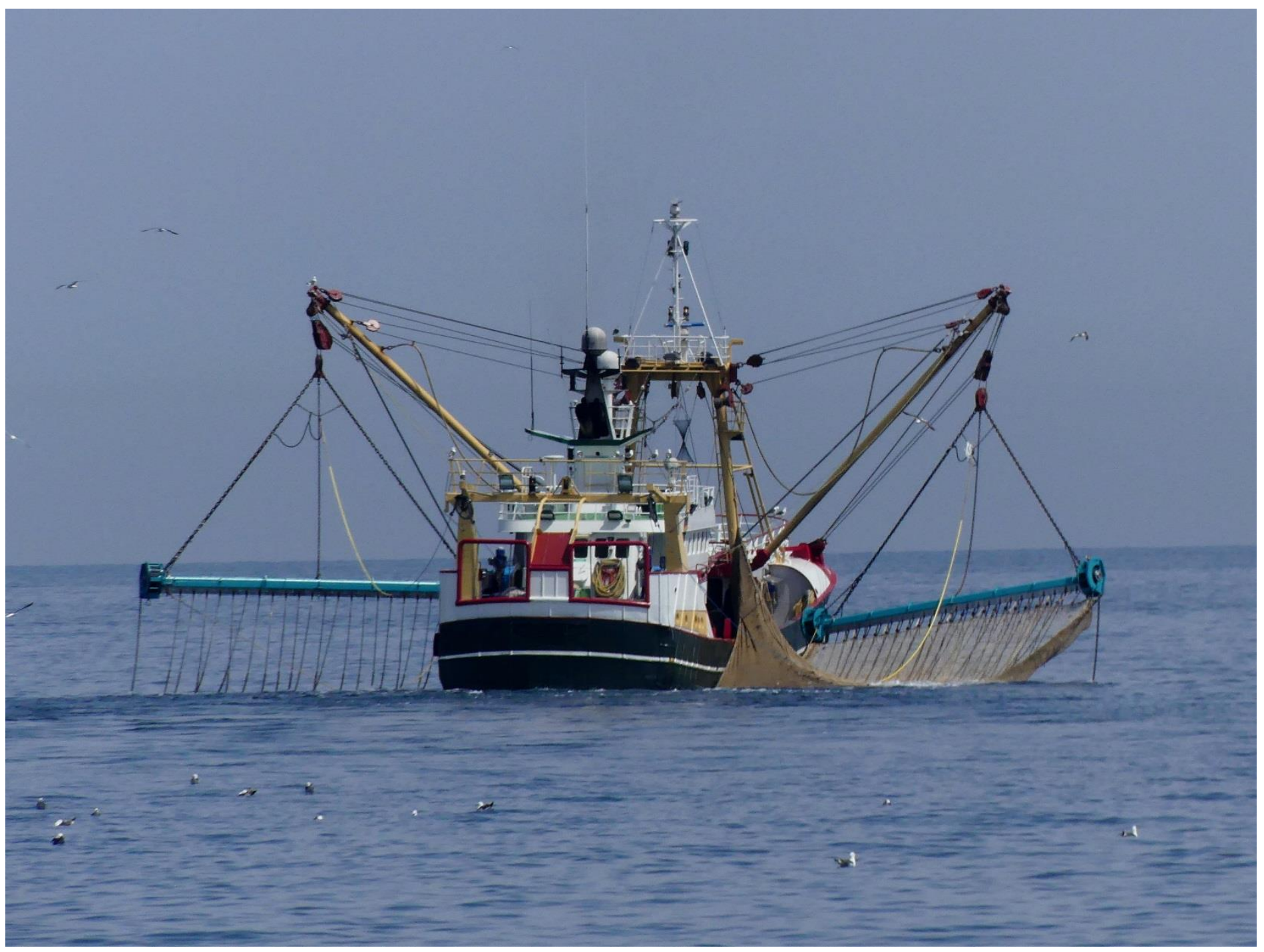

\title{
Direct mortality among demersal fish and benthic organisms in the wake of pulse trawling
}




\section{Direct mortality among demersal fish and benthic organisms in the wake of pulse trawling}

Authors: $\quad$ Edward Schram, Pieke Molenar

This research project was carried out by Wageningen Marine Research at the request of and with funding from the Ministry of Agriculture, Nature and Food Quality for the purposes of Policy Support Research Theme 'BO Nature inclusive Fisheries' (project no. BO-43-023.02-032) 
Keywords: Pulse trawl fisheries, direct mortality, seabed, benthos.

Client: $\quad$ Ministerie van Landbouw, Natuur en Voedselkwaliteit

Attn.: Dhr. Herman Snijders

Postbus 20401

2500 EK, Den Haag

This report can be downloaded for free from https://doi.org/10.18174/504087

Wageningen Marine Research provides no printed copies of reports

Wageningen Marine Research is ISO 9001:2015 certified.

Photo cover: Edward Schram

\section{(C) Wageningen Marine Research}

Wageningen Marine Research, an institute Wageningen Marine Research accepts no liability for consequential damage, nor within the legal entity Stichting for damage resulting from applications of the results of work or other data Wageningen Research (a foundation under obtained from Wageningen Marine Research. Client indemnifies Wageningen Dutch private law) represented by Dr. Marine Research from claims of third parties in connection with this application. M.C.Th. Scholten, Managing Director All rights reserved. No part of this publication may be reproduced and / or

KvK nr. 09098104, published, photocopied or used in any other way without the written permission WMR BTW nr. NL 8113.83.696.B16.

Code BIC/SWIFT address: RABONL2U IBAN code: NL 73 RABO 0373599285 


\section{Contents}

$\begin{array}{llr}1 & \text { Introduction } & 6\end{array}$

$2 \quad$ Materials and Methods $\quad 7$

$\begin{array}{lll}2.1 & \text { Stakeholder consultation } & 7\end{array}$

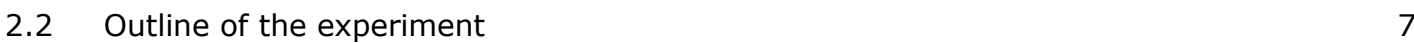

$\begin{array}{lll}2.2 .1 & \text { General set-up } & 7\end{array}$

2.2.2 Location of the experiment $\quad 7$

2.2.3 Trawl specifications and modifications 1

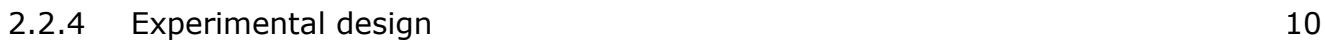

2.3 Sampling and assessment of fish and benthic biota 11

2.3.1 Tows in the pulse trawl tracks 11

2.3.2 Collection and processing of samples 12

2.3.3 Sampled species $\quad 12$

2.3.4 Assessment of the condition of fish and invertebrates $\quad 12$

2.4 Video observations to confirm sampling inside the pulse trawl tracks 13

$\begin{array}{lll}2.4 .1 & \text { Video observations } & 13\end{array}$

$\begin{array}{ll}2.4 .2 & \text { Analysis of video footage }\end{array}$

2.5 Additional data collection $\quad 14$

2.5.1 Catch composition 14

2.5.2 Mesh size shrimp trawl 14

2.5.3 Experimental conditions 14

2.6 Data analysis $\quad 15$

$\begin{array}{llr}3 & \text { Results } & 17\end{array}$

3.1 Sampling inside the pulse trawl tracks $\quad 17$

$\begin{array}{ll}3.1 .1 & \text { Application of WASSP sonar }\end{array}$

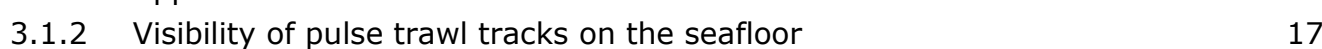

$\begin{array}{ll}\text { 3.1.3 Swept area of pulse trawl tracks by sampling tows } & 17\end{array}$

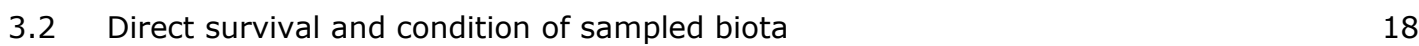

3.2.1 Direct survival of fish and invertebrates $\quad 18$

$\begin{array}{ll}3.2 .2 & \text { Condition of fish }\end{array}$

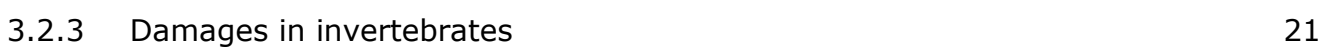

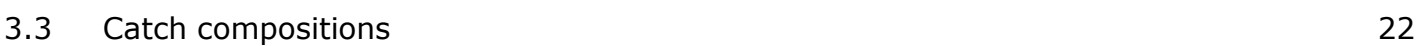

3.3.1 Samples collected by the shrimp trawler $\quad 22$

$\begin{array}{ll}\text { 3.3.2 Catches by the pulse trawler } & 23\end{array}$

4 Discussion $r 2$

4.1 General $\quad 24$

$\begin{array}{ll}4.2 & \text { Sampling of biota from pulse trawl tracks }\end{array}$

$\begin{array}{ll}4.3 & \text { Experimental design }\end{array}$

\begin{tabular}{ll}
4.4 & Direct survival of fish \\
\hline
\end{tabular}

$\begin{array}{lll}4.5 & \text { Direct survival of invertebrates } & 26\end{array}$

$5 \quad$ Conclusions and recommendations $\quad 27$

$\begin{array}{llr}5.1 & \text { Methodology } & 27\end{array}$ 
6 Acknowledgements

$7 \quad$ Quality Assurance

29

References

30

Justification

31 


\section{Summary}

Pulse trawl fisheries involve the use of electrical pulses to immobilize (cramp) target species and make them available for capture. A major concern related to pulse trawl fisheries is the passing pulse trawl causing direct, mass mortalities among benthic organisms, resulting in a 'graveyard' in the wake of a pulse trawler. This has never been investigated in situ and the current pilot study therefore aimed to develop a method for in situ assessments and to perform a first assessment.

A pulse trawler equipped with double rigs made pulse trawl tracks specific for the current experiment. Within 15 to 30 minutes after passage of the pulse trawler, one of its trawl tracks was sampled with a shrimp trawler by a 10 minute tow with a small mesh shrimp beam trawl while the other, similar shrimp trawl was deployed outside the pulse trawl track to obtain control samples. The experiment consisted of two pulse trawl track treatments: a complete pulse trawl and a pulse trawl with its netting and ground rope removed to minimize its mechanical impact. This allowed for isolating electrical from mechanical impacts. In total two paired samples of treatments and controls were obtained per pulse trawl track treatment. The condition of three fish species and three species of invertebrates was assessed. Fish species included plaice (Pleuronectus platessa), dab (Limanda limanda) and solenette (Buglossidium luteum). Invertebrate species included flying crab (Liocarcinus holsatus), hermit crabs (Paguroidea spp.) and brittle stars (Ophiuroidea spp.). Direct survival ranged from $91-100 \%$ among treatments for the fish and $88-100 \%$ for the invertebrates. No significant differences in direct survival were detected between the two treatments and their respective controls for any of the species.

Underwater video observations confirmed deployment of the sampling trawl inside the pulse trawl tracks, although part of swept area was outside the pulse trawl tracks. However, also when correcting the observed direct mortality for this, no differences between treatments and controls were detected. We conclude that with the right equipment, skilled skippers and a calm sea, it is possible to collect biota samples from a track recently trawled by a pulse trawler. However, it is very difficult to sample exclusively from a pulse trawl track; it is inevitable that part of the area swept by a sampling tow lies outside the pulse trawl track aimed for. Despite these limitations, any direct mass mortality caused by a passing pulse trawler would have been recorded in the current study, not only for the systematically observed species but also for other species in the samples. Our study thus did not find any evidence of direct mortality among plaice, dab, solenette, flying crab and brittle stars. 


\section{Introduction}

Demersal pulse-trawl fisheries in the North Sea is a mixed fishery that mainly targets Dover sole (Solea solea) with valuable bycatch of plaice (Pleuronectes platessa), turbot (Scophthalmus maximus) and brill (Scophthalmus rhombus). Pulse fishery involves the use of electrical pulses to startle target species from the seabed and make them available for the capture. Various stakeholders expressed their concerns about the impacts of pulse fisheries, see Quirijns et al. (2018) for an inventory. A major concern is the direct effect of a passing pulse trawl on benthic organisms. It has been claimed by recreational and small scale fisherman from England, Belgium, France and Netherlands that a passing pulse trawl causes mass mortality among benthic organisms, resulting in a 'graveyard' in the wake of a pulse trawler (Bloom, 2018). Direct scientific evidence for such claims is absent (Soetaert et al., 2015a). In fact, over $90 \%$ of undersized fish caught by pulse trawling is alive when landed on deck (Schram and Molenaar, 2018), suggesting that direct mortality among fish exposed to the electric field of a pulse trawl is at least very low. Tank experiments did not provide compelling evidence that the exposure to an electric pulse additional mortality with a number of invertebrate species (Smaal and Brummelhuis, 2005; Soetaert et al., 2015b).

Given this indirect evidence, direct mortality among benthic organisms caused by the exposure to the electric field of a passing pulse trawl seems unlikely. There is ample evidence, however, that mechanical disturbance of bottom trawls may impose direct mortality among benthic invertebrates (Hiddink et al., 2017; Sciberras et al., 2018), although the impact of mechanical disturbance by pulse trawls is less than the impact of traditional beam trawls (ICES, 2018), Nevertheless, concerns about this effect are persistent among stakeholders and the immediate direct effects of pulse trawling have never been investigated in situ. Therefore the current pilot study aimed to develop a method for in situ assessments of direct mortality and to perform a first assessment. The specific objectives of this method development included: 1 . Investigate whether it is possible to detect the track of pulse trawls on the sea floor using WASSP multi beam sonar, 2 . Test whether it is possible to deploy a shrimp trawl in the pulse trawl track to sample benthic organisms from the track, 3. To confirm the deployment of the shrimp trawl in the pulse trawl track by underwater video observations, 4 . To assess the species composition of samples collection in pulse trawl tracks, 5. To explore methods for assessment of the condition of sampled organisms.

To these ends, experimental fishing was conducted during two days in the Southern North Sea, involving a commercial pulse trawler and a shrimp trawler equipped with WASSP multi beam sonar, conventional shrimp beam trawls with a modified ground ropes. In total eight tracks were sampled, of which the last four yielded usable data. 


\section{Materials and Methods}

\subsection{Stakeholder consultation}

Prior to the experiment a stakeholder consultation was held and Dutch small scale fishermen and their representative organisations were invited. The objective of this meeting was twofold. First, we wanted to inform stakeholders on the intended pilot experiment and its objectives. Second, we wanted to get input from stakeholders for the design and organisation of the pilot experiment. Several options for the experimental design were presented and discussed. Finally the meeting opted for the design applied in the current study. Species to be included in the assessment were listed. The meeting also agreed on the delegation of two candidates as independent observers of the experiment, one on each of the two involved vessels. Unfortunately, none of the candidates ultimately joined the experiment as dependent observer. The minutes of the meeting are included in Annex 1.

\subsection{Outline of the experiment}

\subsubsection{General set-up}

The experiment involved two commercial fishing vessels, a pulse trawler and a shrimp trawler, both equipped with their conventional double rig. To study the effect of the electric pulse only, we adjusted the portside pulse trawl by removing the net and ground rope (see experimental design). At sea, the pulse trawler made 35 to 45 minutes tows against the current. The shrimp trawler (with its trawls at the surface) followed the pulse trawler just outside its wake at a distance of approximately $120 \mathrm{~m}$. The shrimp trawler positioned itself such that the pulse trawls were visible on its WASSP F3 multibeam sonar (WASSP Ltd, Auckland, New Zealand). A buoy on a $100 \mathrm{~m}$ rope attached to the end of the boom of the pulse trawler aided to maintain the shrimp trawler in proper position (photo 1 , Annex 2). The shrimp trawler logged its track in the wake of the pulse trawler until a sufficiently long and clear pulse track to allow for a 10 min tow for sampling had been observed in the WASSP sonar. The shrimp trawler then returned the starting position where it deployed one of its trawls in a pulse track to make a 10 min sampling tow in the towing direction of the pulse trawler. The shrimp trawler's port side trawl was deployed in the starboard pulse track or vice versa. The shrimp trawlers other trawl was consequently deployed outside both pulse tracks (Figure 2) and used to obtain reference samples. The shrimp trawl deployed in a pulse track was equipped with two (GOPRO) cameras and lights to obtain visual confirmation of sampling inside the pulse track (photo 2, Annex 2). All tows were made against the tidal current to prevent that benthic organisms were washed out of the pulse track by water currents. The pulse trawler refrained from discarding its unwanted and undersized by-catches in the study area to prevent that discarded organisms were included in the samples. The general set-up of the experiment was concluded after consulting stakeholders on their vision and practical observations at sea.

\subsubsection{Location of the experiment}

The experiment was performed with commercial pulse trawler from the larger segment ( $11 \mathrm{~m}$ wide trawls). This type of pulse vessels is allowed to fish outside the 12 nautical mile zone from the Dutch coast, the experimental location was therefore determined just outside the 12 mile zone. To enable visual trawl path detection on the underwater video recordings a hard sandy sea bottom was chosen west from the harbour of IJmuiden (Figure 1). This sediment type is prevalent among the Dutch coast and provides reasonable visibility as the sand settles on the seabed after trawl passage. 


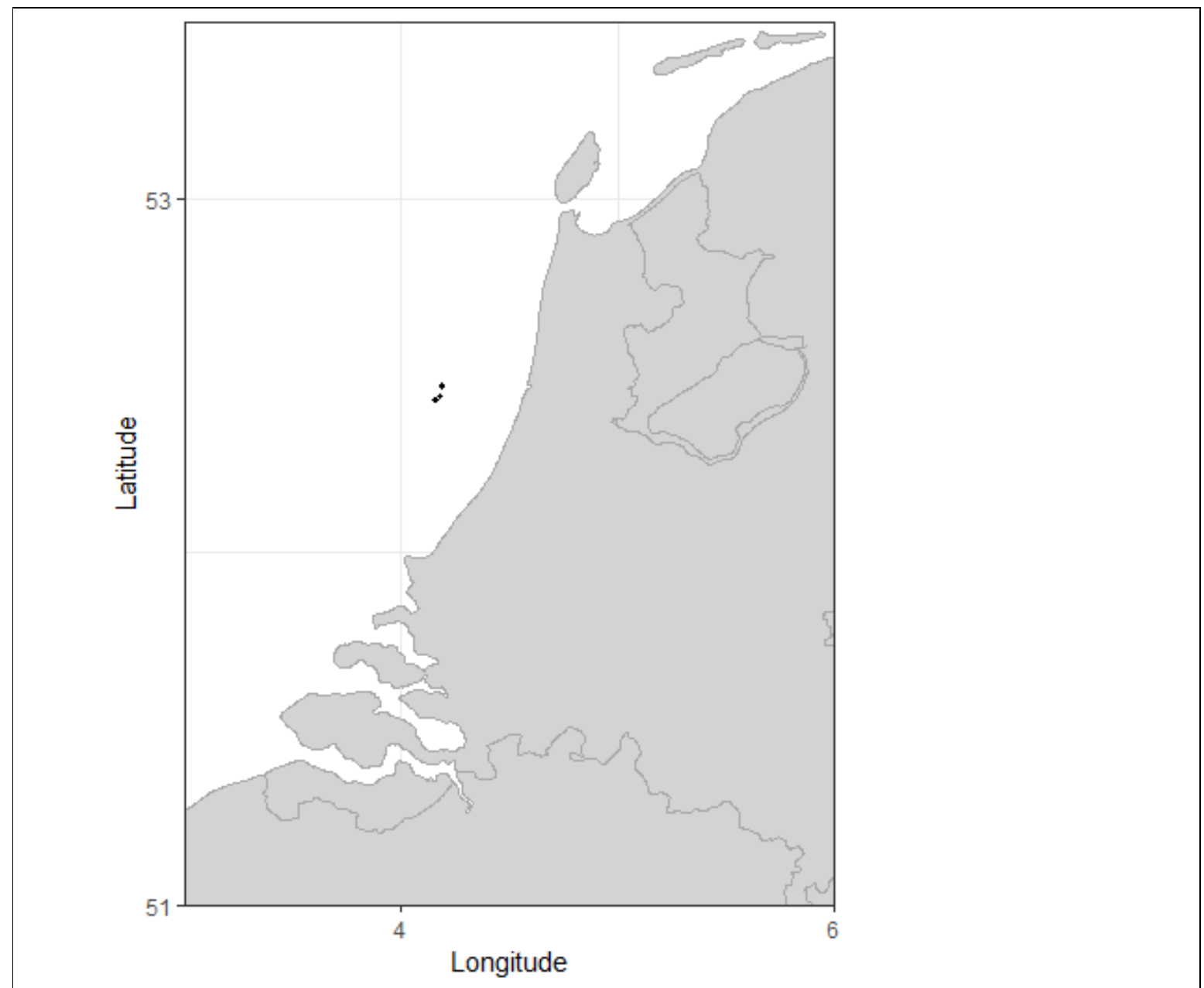

Figure 1. Locations of the experimental tows

\subsubsection{Trawl specifications and modifications}

The trawl dimensions and specifications of the pulse and shrimp trawl are presented in Table 1 and Table 2. To maximize the amount of organisms the shrimp trawls could pick up from the seafloor, the conventional bobbin ground rope of the commercial shrimp trawls were replaced by heavy closed ground ropes consisting of rubber discs supplemented with 97 additional lead discs (0.9kg). (Photo 2, Annex 2).

Both pulse trawls had additional chains $(10 \mathrm{~m}, \varnothing 618 \mathrm{~mm})$ attached to each end of both seawings (Photo 3, Annex 2) to create clearly visible slits on the seafloor that mark the boundaries of the pulse trawl tracks. To prevent technical failures resulting from electrodes touching each other, the electrodes of the pulse trawl without ground rope and net were fixed in parallel position by dyneema ropes between the aft ends of adjacent electrodes (Photo 4, Annex 2). 
Table 1 Electrical characteristics and settings of the pulse trawls.

\begin{tabular}{|c|c|c|}
\hline Specifics & & Setting \\
\hline \multirow[t]{5}{*}{ Electrodes } & Number & 22 \\
\hline & Type & HFK \\
\hline & Total length (m) & 7.23 \\
\hline & Distance between electrodes $(\mathrm{cm})$ & 42 \\
\hline & $\begin{array}{l}\text { Total length electrodes on seabed (pulse } \\
\text { field) }(\mathrm{m})\end{array}$ & 4.40 \\
\hline \multirow[t]{4}{*}{ Conductor elements } & Number per electrode & 11 \\
\hline & Diameter (mm) & 33 \\
\hline & Length $(\mathrm{mm})$ & 125 \\
\hline & Distance between elements (mm) & 420 \\
\hline \multirow[t]{3}{*}{ Isolator } & Number per electrode & $1+9$ (disc isolators) \\
\hline & Length $(\mathrm{mm})$ & $1030(1 \mathrm{x}) \& 230$ (disc isolators) \\
\hline & Diameter (mm) & 60 \\
\hline \multirow[t]{5}{*}{ Pulse } & Power (kW/trawl) & $4.8-5.8$ \\
\hline & Width $(\mu s)$ & $330-350$ \\
\hline & Frequency $(\mathrm{Hz})$ & 60 \\
\hline & Peak voltage over electrode (V) & 57 \\
\hline & $\begin{array}{l}\text { Maximum exposure to pulse field } \\
(\mathrm{sec} .)\end{array}$ & 1.82 \\
\hline
\end{tabular}


Table 2 Vessel and trawl specifics of the pulse trawler and shrimp trawler

\begin{tabular}{|c|c|c|c|}
\hline \multicolumn{2}{|l|}{ Specifics } & \multirow{2}{*}{$\begin{array}{l}\text { Pulse trawler } \\
\text { Making pulse trawl } \\
\text { tracks }\end{array}$} & \multirow{2}{*}{$\begin{array}{l}\text { Shrimp trawler } \\
\text { Sampling pulse } \\
\text { trawl tracks }\end{array}$} \\
\hline Vessel & $\begin{array}{l}\text { Role in the } \\
\text { experiment }\end{array}$ & & \\
\hline & Engine power $(\mathrm{Kw})$ & 749 & 221 \\
\hline & Tonnage (GT) & 269 & 137 \\
\hline & Length (m) & 32 & 24 \\
\hline & Trawl & Seawing pulse & Beam trawl shrimp \\
\hline & Number of trawls & 2 & 2 \\
\hline & Fishing speed (kts) & $4.5-5.0$ & 3.0 \\
\hline \multirow[t]{4}{*}{ Beam / Seawing } & Width (m) & 11 & $\begin{array}{l}9 \text { ( } 8.84 \text { between } \\
\text { shoes) }\end{array}$ \\
\hline & Length (m) & n.a. & n.a. \\
\hline & $\begin{array}{l}\text { Beam diameter } \\
(\mathrm{cm})\end{array}$ & n.a. & 15.2 \\
\hline & Total weight $(\mathrm{kg})$ & 2500 & 1300 \\
\hline \multirow[t]{4}{*}{ Beam shoes } & Number per trawl & n.a. & 2 \\
\hline & Width (mm) & n.a. & 40 \\
\hline & Length (mm) & n.a. & 113 \\
\hline & Height $(\mathrm{cm})$ & n.a. & 70 \\
\hline \multirow[t]{5}{*}{ Ground rope } & Type & Rubber discs & $\begin{array}{l}\text { Rubber \& lead discs } \\
\text { ( } 97 \text { discs of } 0.9 \mathrm{~kg} \\
\text { each) }\end{array}$ \\
\hline & Length (m) & 10 & 11.5 \\
\hline & $\begin{array}{l}\text { Diameter discs } \\
(\mathrm{mm})\end{array}$ & 200 & 100 \\
\hline & $\begin{array}{l}\text { Diameter ground } \\
\text { rope chain/cable } \\
(\mathrm{mm})\end{array}$ & 22 (chain) & 14 (cable) \\
\hline & Total weight $(\mathrm{kg})$ & Unknown & 181 \\
\hline \multirow[t]{4}{*}{ Trawl } & Total length (m) & 27 & 21.4 \\
\hline & $\begin{array}{l}\text { Mesh size cod-end } \\
(\mathrm{mm})\end{array}$ & $80+$ & 19.2 \\
\hline & Twine cod-end & PE & nylon \\
\hline & $\begin{array}{l}\text { Twine thickness } \\
(\mathrm{mm})\end{array}$ & 3 & $1.5(210 / 30)$ \\
\hline
\end{tabular}

\subsubsection{Experimental design}

The experiment consisted of paired tows by a shrimp trawl in one trawl track of the pulse trawler and the other shrimp trawl in the reference area outside the track. Two treatments were imposed that created a pulse trawl track of (1) a complete pulse trawl including ground rope and net (treatment PULSE_CMPLT); (2) a pulse trawl with its netting and ground rope removed (treatment PULSE_NO NET) (Photo 5, Annex 2). Comparison of the two treatments allowed for isolating the electrical impact on benthic organisms from mechanical impacts of pulse trawls. Treatments were conducted in separate tows with two tows per treatment. Upon deployment of the shrimp trawl in a pulse track, the other shrimp trawl was deployed outside the pulse tracks to obtain a control sample (CTRL, Figure 2). This design resulted in paired samples of treatments and controls for all tows. Towing time was limited to 10 minutes to minimize the impact of retention in the cod-ends on the sampled specimens. All samples were collected between 15 and 30 minutes after the passage of the pulse trawl. 


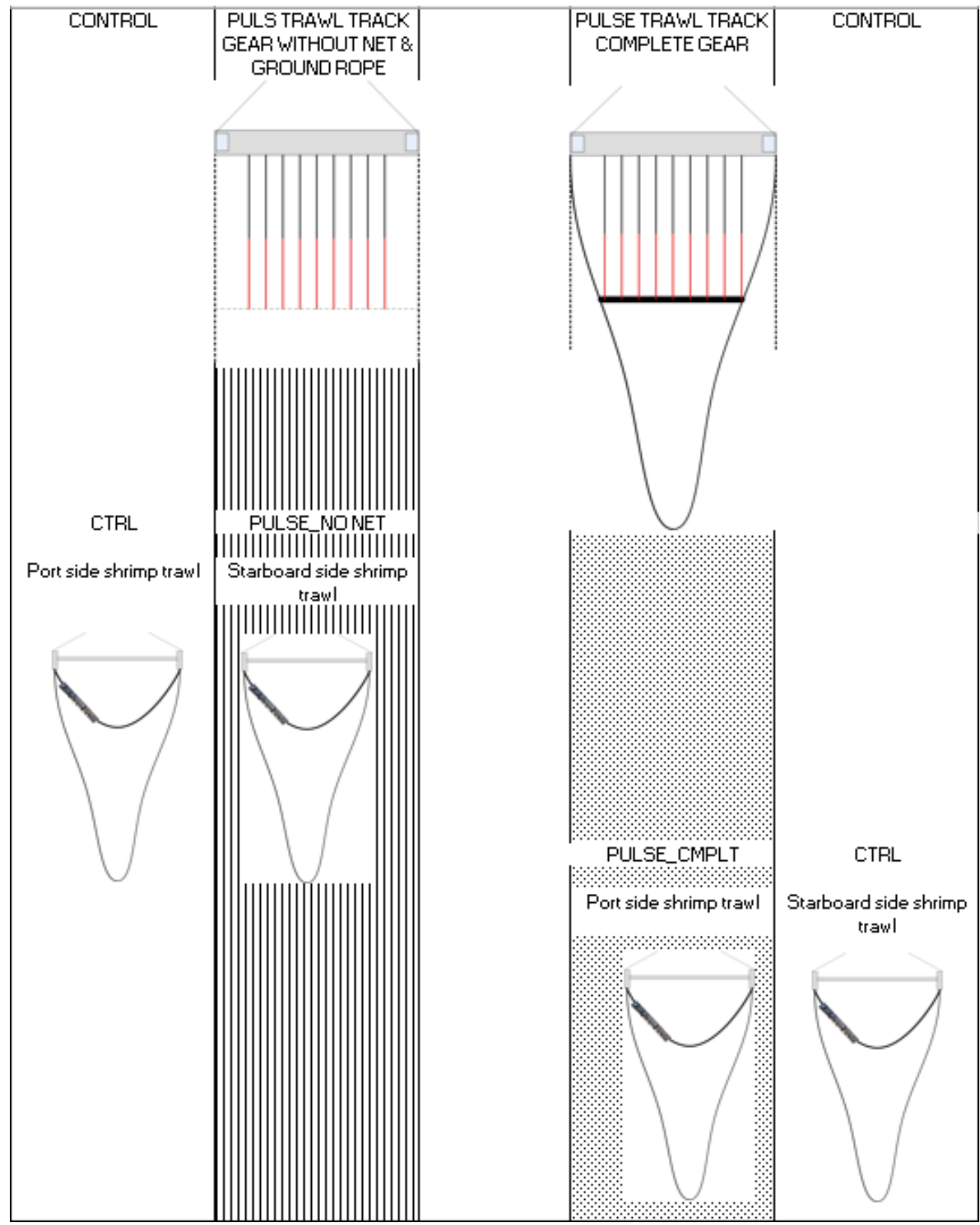

Figure 2. Schematic presentation of the experimental set up. Paired samples for PULS NO NET and CTRL and for PULSE_CMPLT and CTRL were collected by deploying the shrimp trawls in and next to the respective pulse trawl tracks.

\subsection{Sampling and assessment of fish and benthic biota}

\subsubsection{Tows in the pulse trawl tracks}

In total eight tows by the pulse trawler were tracked by the shrimp trawler. Pulse trawl tows 1 and 4 were tracked to test the method (piloting) and not sampled. The objective of tows 2, 3 and 5 to 8 was to collect samples from the pulse trawl tracks. For tows 2 and 3 video observation confirmed that samples had not been taken inside the intended pulse tracks and these samples were consequently discarded. For tows 5 to 8 video observations confirmed successful deployment of the shrimp trawl inside the intended pulse tracks during part of the tows and these tows yielded usable samples. Table 3 provides an overview of the characteristics of the sampled tows. 
Table 3. Characteristics of the experimental tows. CTRL: Control sample collected outside pulse trawl tracks. PULSE_CMPLT: Treatment sample collected from the track of the complete pulse trawl. PULSE_NO NET: Treatment sample collected from the track of the pulse trawl without ground rope and net.

\begin{tabular}{|c|c|c|c|c|}
\hline \multirow{2}{*}{$\begin{array}{c}\text { Pulse trawl and } \\
\text { shrimp trawl tow } \\
\text { nr. }\end{array}$} & \multirow[t]{2}{*}{ Objective } & \multicolumn{2}{|c|}{$\begin{array}{c}\text { Sampled pulse trawl track / } \\
\text { Treatment }\end{array}$} & \multirow[t]{2}{*}{$\begin{array}{l}\text { Sampling in pulse trawl } \\
\text { tracks video confirmed }\end{array}$} \\
\hline & & $\begin{array}{c}\text { Starboard side } \\
\text { shrimp trawl }\end{array}$ & $\begin{array}{l}\text { Port side shrimp } \\
\text { trawl }\end{array}$ & \\
\hline 1 & Piloting & Both & Both & n.a. \\
\hline 2 & Sampling & CTRL & PULSE_CMPLT & No \\
\hline 3 & Sampling & CTRL & PULSE_CMPLT & No \\
\hline 4 & Piloting & Both & Both & n.a. \\
\hline 5 & Sampling & CTRL & PULSE_CMPLT & Yes \\
\hline 6 & Sampling & PULSE_NO NET & CTRL & Yes \\
\hline 7 & Sampling & PULSE_NO NET & CTRL & Yes \\
\hline 8 & Sampling & CTRL & PULSE_CMPLT & Yes \\
\hline
\end{tabular}

\subsubsection{Collection and processing of samples}

Samples were collected by 10-12 minute tows with modified shrimp beam trawls. Catches of the port and starboard side shrimp trawls were discharged simultaneously but separately into 50L plastic baskets, each placed inside a plastic tub filled with surface seawater. Each tub was aerated to supply oxygen and thereby prevent suffocation of biota during storage. Benthic organisms were sampled as follows. The contents of a basket, the sample, was mixed manually and then a sub sample of approximately $2 \mathrm{~L}$ was netted from the basket. The sub-sample was placed in a $30 \mathrm{~L}$ rectangular plastic tub filled with seawater. Specimens of interest were manually picked from the tub and placed in water filled containers. Per sample all sub-sampled fish were placed in a single $105 \mathrm{~L}$ container filled with aerated seawater (Photo 6, Annex 2). For the invertebrate species we used separate containers per species with stagnant water which was regularly renewed to maintain proper water quality. If needed, a second or third sub-sample was taken from the basket holding the full sample to obtain at least 20 specimens per species. Sampling of benthic organisms and fish was completed for both samples before we proceeded to assess the condition of the specimens. Sampling and assessment of the condition of the specimens in the samples was alternated between treatments within the paired samples.

\subsubsection{Sampled species}

The selection of species to be sampled was based on the list of species resulting from the stakeholder consultation prior to the experiment (see 2.1) and species abundances in the first catches. To keep the time required to process all samples within practical limits, sampling was limited to six species: three fish species and three species of invertebrates. Fish species included plaice (Pleuronectus platessa), dab (Limanda limanda) and solenette (Buglossidium luteum). Invertebrate species included flying crab (Liocarcinus holsatus), hermit crabs (Paguroidea spp.) and brittle stars (Ophiuroidea spp.).

\subsubsection{Assessment of the condition of fish and invertebrates}

For each species we aimed to collect a minimum of 20 specimens from each sample. However, not in all cases sufficient numbers were present in the sample to obtain this sample size. For all sampled specimens we established whether individuals were dead or alive. Specimens that displayed any kind of movement were considered to be alive. Specimens that displayed no movement or were crushed were considered to be dead. Only in case of brittle stars it was in some cases impossible to determine whether specimen with absent movements was dead and these cases were recorded as 'unknown'. Within each sample the condition of 10 specimens per species was assessed in more detail. 
Fish condition was assessed in more detail by scoring vitality indices and damages according to Van der Reijden et al. (2017). Damages in invertebrates were assessed in more detail according to Bergman et al. (2000). Table 4 provides a description of the criteria used to score vitality and damages. After completion of the condition assessment all sub-samples were returned to their sample of origin and included in the catch composition assessment (see below).

Approximately ten fish that had obviously been dead for longer periods than the time between passage of the pulse trawler and sampling appeared in the samples, as judged on their appearance. This judgement included characteristics such as the presence of rigor mortis and obvious signs of prolonged decay such as loose or missing skin and eyes, ruptured abdominal cavities and unpleasant smell. These fish were excluded from the samples.

Table 4. Description of vitality index and damage scoring

\begin{tabular}{|c|c|}
\hline \multicolumn{2}{|c|}{ Vitality index - All fish species } \\
\hline Class & Description \\
\hline A & Fish lively, no visible signs of loss of scale or mucus layer. \\
\hline$B$ & $\begin{array}{l}\text { Fish less lively, minor lesions and some scales missing, mucus layer } \\
\text { affected up to } 20 \% \text { of skin surface area, some point haemorrhaging on the } \\
\text { blind side. }\end{array}$ \\
\hline C & $\begin{array}{l}\text { Fish lethargic, intermediate lesions and some patches without scales, } \\
\text { mucus layer affected up to } 50 \% \text { of skin surface area, several point } \\
\text { haemorrhaging on the blind side. }\end{array}$ \\
\hline $\mathrm{D}$ & $\begin{array}{l}\text { Fish lethargic or dead, clear head haemorrhaging, major lesions and } \\
\text { patches without scales, mucus layer affected for more than } 50 \% \text { of the skin } \\
\text { surface area, significant point haemorrhaging on the blind side. }\end{array}$ \\
\hline \multicolumn{2}{|c|}{ Damage scores - All fish species } \\
\hline Damage & Description ( 1 = present; $0=$ absent) \\
\hline Fins & Fins are damaged or split (including tail fin). \\
\hline$>50 \%$ & $\begin{array}{l}\text { Damage to skin surface, scale or mucus layer at more than } 50 \% \text { of the } \\
\text { dorsal body surface. }\end{array}$ \\
\hline Head haemorrhages & Presence of a haemorrhage in the head of the fish \\
\hline $\begin{array}{l}\text { Hypodermic } \\
\text { haemorrhages }\end{array}$ & Presence of a hypodermic haemorrhage \\
\hline Intestines & $\begin{array}{l}\text { Intestines are protruding or are visible through damaged body tissue of the } \\
\text { fish. }\end{array}$ \\
\hline Wound & Presence of a wound such that flesh is visible. \\
\hline \multicolumn{2}{|c|}{ Damage scores - Invertebrates } \\
\hline Damage & Description ( 1 = present; $0=$ absent) \\
\hline Limbs & Crabs \& starfish: one or more limbs or arms (partly) lost. \\
\hline Crushed & Crabs \& starfish: Carapace (crabs) or disc (stars) damaged or crushed \\
\hline Shell - undamaged & Hermit crabs: shell lost but undamaged \\
\hline Shell damaged & Hermit crabs: shell lost and damaged \\
\hline
\end{tabular}

\subsection{Video observations to confirm sampling inside the pulse trawl tracks}

\subsubsection{Video observations}

The shrimp trawl was equipped with two forward looking cameras (GOPRO Hero 4) inside the right and left extremities of the beam (Photo 2, Annex 2) towed inside the pulse trawl track. Diving lights (Deep Blue 3500 lux) were installed next to each camera to increase visibility. 


\subsubsection{Analysis of video footage}

For each sampled tow, video footage and time recordings by the video cameras were used to estimate to what extent the pulse trawl track had been swept by the shrimp trawl during a tow. To this end we first determined the exact time on the seafloor as the time difference between the trawl reaching and leaving the seafloor. We then determined the time points at which the left and right shoe of the shrimp trawl entered or left the pulse trawl track as could be observed from the shoes passing the slits drawn in the seafloor by the chains attached to each end of the pulse trawls. Visual positioning of right shoe of the shrimp trawl allowed us to position the left shoe $9 \mathrm{~m}$ (the width of the shrimp beam trawl) to the left at the same time point, and vice versa. In addition to the slits drawn by the chains, the electrodes of pulse trawl without net and ground rope also drew visible slits in the seafloor. This allowed us to determine the position the shoes of shrimp trawl in the pulse trawl track at multiple times points. For the complete pulse trawl this was not possible as slits by the electrodes were not visible. The so obtained set of positions of the shrimp trawl were used to reconstruct the path of the shrimp trawl relative to the pulse trawl track for each sampled tow. To prevent over estimation of the area swept inside the pulse trawl track during tow 5, we introduced artificial positions of the shrimp trawl between subsequent exit and entry points of the same shoe. We then assumed the shrimp trawl to be $50 \%$ outside the pulse trawl track during the respective time frame (see also Results section). Note that the pulse trawl track (11 meter) was wider than the shrimp trawl ( 9 meter), both shoes of the shrimp trawl could be inside the pulse track at the same time. The area swept inside the pulse trawl track by the shrimp trawl was expressed as percentage of the total swept area during a tow.

\subsection{Additional data collection}

\subsubsection{Catch composition}

The species composition of each entire sample was determined directly after assessment of the condition of sub-sampled fish and invertebrates (see 2.3.4). To this end each sample was sorted by species. Total biomass of each species group was determined. Sub-samples used for the assessment of condition of fish and invertebrates were included when determining catch composition.

\subsubsection{Mesh size shrimp trawl}

Mesh size of both shrimp trawls was determined by measuring the size of 20 stretched meshes in the cod-end of each trawl (MARELEC OMEGA Mesh gauge, MARELEC Food Technologies, Belgium). The results of the mesh size measurements are included in Table 2.

\subsubsection{Experimental conditions}

To describe the experiment and the experimental conditions various parameters were recorded for the tows by the pulse trawler and the sampling tows by the shrimp trawler. Pulse trawl track data were recorded by the skipper of the pulse trawler after instruction by a researcher. For the shrimp trawler the records were kept by the researchers on board in cooperation with the skipper. Experimental conditions are presented in Table 5. Next to those parameters the dates and times of shooting and hauling the trawls were recorded for both vessels. 
Table 5. Experimental conditions. Parameters were recorded per sampled tow. Presented are the minimum and maximum values recorded (range).

\begin{tabular}{|c|c|c|c|}
\hline Parameter & Pulse trawler & Shrimp trawler & Method \\
\hline Wave height & n.r. & $0.2-0.5 \mathrm{~m}$ & \multirow{3}{*}{ Skipper's estimate } \\
\hline Wind direction & E-W-SW & E-W-SW & \\
\hline Wind speed & $0-2 \mathrm{Bft}$ & $0-2 \mathrm{Bft}$ & \\
\hline Seafloor type & Sandy / hard & Sandy / hard & $\begin{array}{l}\text { Skipper's knowledge \& } \\
\text { echo sounder equipment }\end{array}$ \\
\hline Speed over water & 4.7-5.0 kts & $3.3-4.1 \mathrm{kts}$ & \multirow{6}{*}{$\begin{array}{l}\text { Vessel's navigation } \\
\text { equipment. } \\
\text { 1) plus sea gauge pulse } \\
\text { trawler } \\
\text { 2) shift of tide between } \\
\text { making pulse track \& } \\
\text { sampling }\end{array}$} \\
\hline Speed over seafloor & $4.0-4.5 \mathrm{kts}$ & $2.7-3.8 \mathrm{kts}$ & \\
\hline Direction & $20^{\circ}-200^{\circ}$ & $18^{\circ}-205^{\circ}$ & \\
\hline Water depth & $21-23 \mathrm{~m}^{1)}$ & $24-27 \mathrm{~m}$ & \\
\hline Current direction & $\mathrm{NE}$ & $0-21 \& 180^{2)}$ & \\
\hline Current speed & $0.8-2.2 \mathrm{kts}$ & & \\
\hline Water temperature & $11-13.2^{\circ} \mathrm{C}^{3)}$ & $16.3^{\circ} \mathrm{C}^{4)}$ & $\begin{array}{l}\text { 3) Sensor on pulse trawl } \\
\text { 4)Hach Lange Multimeter }\end{array}$ \\
\hline
\end{tabular}

\subsection{Data analysis}

Direct survival was measured at the level of the individual fish. Fish were either dead or alive upon sampling; directly after landing catches on deck. Direct survival probability was determined per tow and per species by expressing counts of fish alive upon sampling as a percentage of the total number of fish assessed.

Fish condition of individual fish was expressed using a vitality index score with classes A, B, C and D, resulting in counts per index score per treatment for each species. Using these counts, fish condition per treatment and species was expressed as the frequency of individual vitality index scores within the group formed by treatment and species.

Direct survival and fish condition were tested for differences between one of two pulse trawl track treatments and its associated controls (PULSE_CMPLT vs CTRL and PULSE_NO NET vs CTRL) using Fisher's exact test. The two pulse trawl track treatments (PULSE_CMPLT vs PULSE_NO NET) were tested for differences in direct survival using Fisher's exact test.

Direct survival measured in samples collected from the pulse trawl tracks (PULSE_CMPLT and PULSE_NO NET) was corrected for the area swept inside the pulse trawl track during the sampling tow, as follows:

Corrected direct survival PULSE $=($ Direct survival PULSE - \%outside* direct survival CTRL) $/ \%$ inside

Where:

- $\%$ outside = area swept outside pulse trawl track (\% of total area swept).

- $\quad \%$ inside $==$ area swept inside pulse trawl track (\% of total area swept).

- Direct survival CRTL = direct survival as observed for the control tow paired to the tow in the pulse trawl track.

- $\quad$ Direct survival PULSE = direct survival as observed for the tow partially in the pulse trawl track (PULSE_CMPLT or (PULSE_NO_NET).

Here we assume that direct survival of specimens collected outside the pulse trawl track equals the survival of specimens of the same species as observed for the control tow paired to the tow in the pulse trawl track. We also assume that specimens were homogeneously distributed over the seafloor and that the proportions of specimens collected either inside or outside the pulse trawl track are proportional to the areas swept in and outside the pulse trawl tracks. Direct survival was only 
corrected in case it was lower than the survival observed for the related control tows; correction never led to a higher survival for the pulse trawl tracks. Corrected direct survival was tested for differences between one of two pulse trawl track treatments and its associated controls using Fisher's exact test 


\section{Results}

\subsection{Sampling inside the pulse trawl tracks}

\subsubsection{Application of WASSP sonar}

The WASSP sonar on the shrimp trawler used to locate the exact track of both pulse trawls showed clearly the pulse trawls while deployed on the seabed (Photo 11 left, Annex 2). The first detection trials showed that this was only possible as the WASSP sonar was not disturbed by the turbulent screw water of the pulse trawler, therefore the shrimp trawler was located exactly above the trawl on either left of the portside or right side of the starboard trawl. When positioned correctly (150m behind de pulse trawler, exactly the same speed) both trawls were visible, but the second trawl further from the vessel was not as obvious (photo 11 right, Annex 2). In the same picture the seabed profile is visible with large sand dunes over the track. The signal of the trawl was better visible on softer sediment On hard sand the signal disappeared, this might be due to WASSP settings. For the Pulse trawl with net it was possible to notice the width of the netting and thus the position of the vessel above the trawl. When the vessel was positioned above the beam a wide red signal was visible with indications of the actual beam, where positioned down to the cod-end the signal appeared to be smaller similar to the net. To deploy the shrimp trawl in the pulse trawl we aimed to follow the centre of the pulse track with end of the boom of the shrimp trawler (Photo 11 left, Annex 2).

\subsubsection{Visibility of pulse trawl tracks on the seafloor}

The pulse trawl tracks were clearly visible on the video footage. The seafloor that had not been swept by the pulse trawl showed wave-shaped sandy ridges (Photo 7, Annex 2). The boundaries between unswept seafloor and the pulse trawl tracks were clearly marked by the deeper slits caused by the chains attached to the extremities of both seawings (Photo 8, Annex 2). Inside the track made by the complete pulse trawl, with net and ground rope, the sandy seafloor had been smoothed out; the wave-shaped sandy ridges had disappeared (Photo 9, Annex 2). Inside the track made by the pulse trawl without net and ground rope, parallel slits drawn by the pulse modules were clearly visible in the sand. Between these slits, the wave-shaped ridges were still present (Photo 10, Annex 2).

\subsubsection{Swept area of pulse trawl tracks by sampling tows}

The areas swept inside the pulse trawl tracks with the shrimp trawl, expressed as percentages of the total swept areas, were estimated at $80 \%$ for tow $5,45 \%$ for tow $6,49 \%$ for tow 7 and $43 \%$ for tow 8 of the total area swept by the shrimp trawl during each of the sampling tows. Figure 3 shows the reconstructed trawl paths of the shrimp trawl relative to the pulse trawl tracks. 


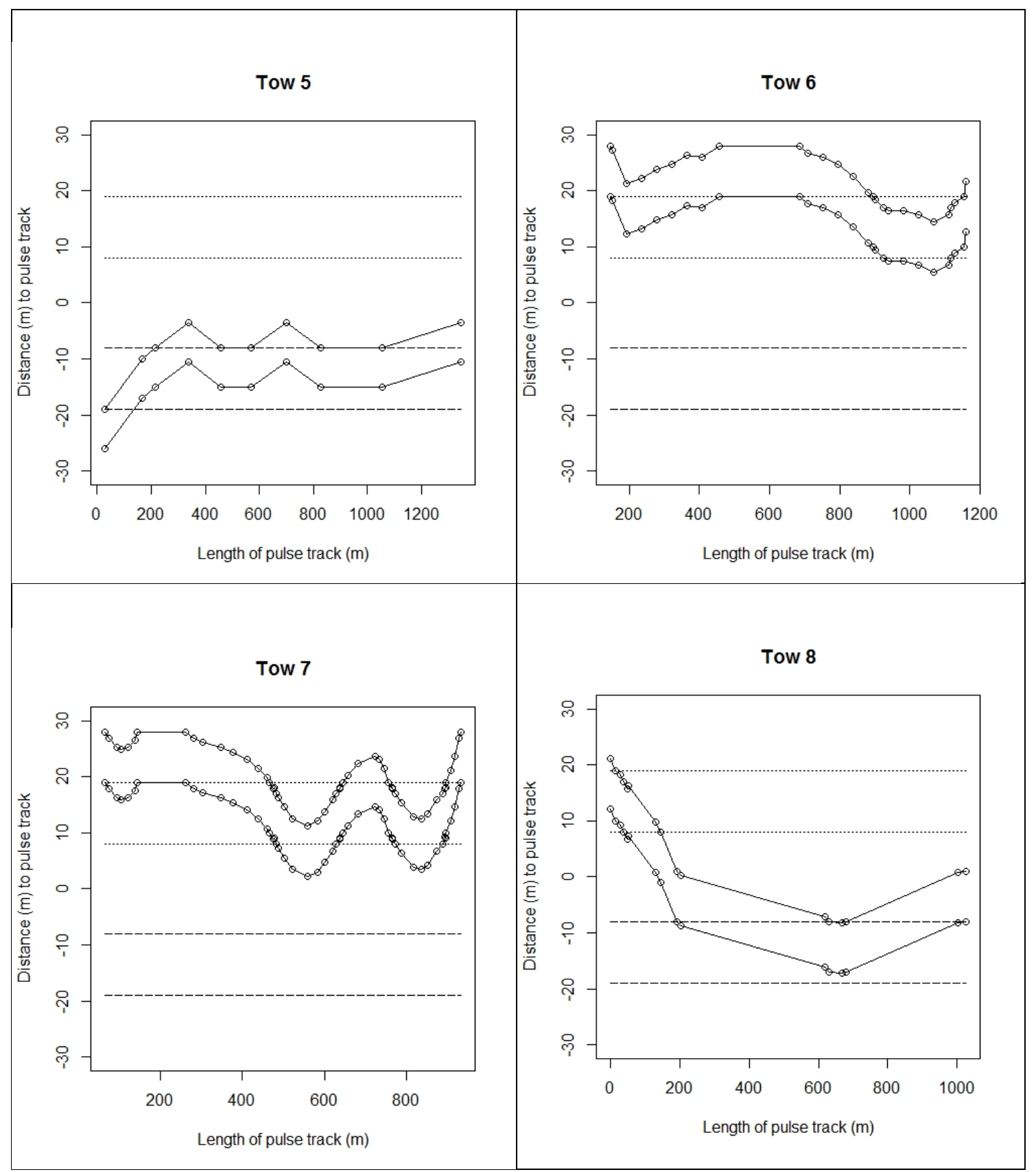

Figure 3. Observed positions (o) and reconstructed paths (closed lines) of the shrimp trawl relative to the pulse trawl tracks for sampling tows 5, 6, 7 and 8. The tracks by the complete (PULSE_CMPLT) and the pulse trawl without net and ground rope (PULSE_NO_NET) are respectively shown by the dotted (top) and dashed (bottom) horizontal lines. The centreline of the pulse trawler is positioned at $0 \mathrm{~m}$ on the $\mathrm{y}$-axis. The distance of $16 \mathrm{~m}$ between the two $11 \mathrm{~m}$ wide pulse trawls then positions the portside pulse trawl track (PULSE_NO_NET) between 8 and $11 \mathrm{~m}$ and the starboard side pulse trawl track (PULSE_CMPLT) between -8 and -19 on the $y$-axis.

\subsection{Direct survival and condition of sampled biota}

\subsubsection{Direct survival of fish and invertebrates}

The percentage of fish and invertebrates alive upon sampling, i.e. direct survival after landing catches on deck, are presented for all sampled species per treatment and its respective controls in Table 6. . Overall, the majority of sampled animals was alive upon sampling, resulting in direct survivals ranging from $91-100 \%$ among treatments for the fish and $88-100 \%$ for the invertebrates. No significant differences in direct survival were detected between the two treatments and their respective controls for any of the species. Also between the two pulse trawl track treatments 
(PULSE_CMPLT vS PULSE_NO NET) no differences in direct survival were detected for any of the species ( $p$-values not shown). Table 6 also shows the direct survival for the pulse trawl tracks corrected for the actual area swept inside the pulse trawl tracks. This correction was made only in cases where direct survival of the control treatment for the same tow was higher than the direct survival observed for the pulse trawl track. The corrected direct survival percentages are slightly lower than when uncorrected. Despite this, no differences between corrected direct survival in the pulse trawl tracks and the controls were detected.

Table 6. Direct survival of fish and invertebrates from pulse trawl tracks made by a complete trawl (PULSE_CMPLT), pulse trawl tracks made by a pulse trawl without ground rope and net (PULSE_NO NET) and for unfished control areas (CTRL). In case direct survival for controls $>$ pulse trawl tracks, the direct survival for pulse trawl tracks was corrected for the area swept inside the pulse trawl tracks. Note that paired samples were obtained for treatment and controls; each treatment has its own controls. For pairs of treatment and control with a p-value $<0.05$ (Fisher's exact test) the direct survival is considered to differ significantly.

\begin{tabular}{|c|c|c|c|c|c|c|}
\hline \multirow[t]{2}{*}{ Species } & \multirow[t]{2}{*}{ Treatment } & \multicolumn{3}{|c|}{$\begin{array}{l}\text { Not corrected for area swept } \\
\text { inside pulse track }\end{array}$} & \multicolumn{2}{|c|}{$\begin{array}{l}\text { Corrected for area swept } \\
\text { inside pulse track }\end{array}$} \\
\hline & & $\begin{array}{l}\text { Total } \mathrm{N} \\
\text { sampled }\end{array}$ & \begin{tabular}{|l|} 
Direct \\
survival \\
(\% of total \\
sampled)
\end{tabular} & $\begin{array}{l}\text { p-value } \\
\text { Fisher's } \\
\text { exact } \\
\text { test. }\end{array}$ & $\begin{array}{l}\text { Direct survival } \\
\text { (\% of total } \\
\text { sampled) }\end{array}$ & $\begin{array}{l}\text { p-value } \\
\text { Fisher's } \\
\text { exact test. }\end{array}$ \\
\hline \multirow{4}{*}{$\begin{array}{l}\text { Plaice } \\
\text { (Pleuronectes } \\
\text { platessa) }\end{array}$} & PULSE_CMPLT & 36 & $100 \%$ & \multirow{2}{*}{\} 1.0} & & \\
\hline & CTRL & 39 & $98 \%$ & & & \\
\hline & $\begin{array}{l}\text { PULSE_NO } \\
\text { NET }\end{array}$ & 45 & $100 \%$ & \}n.a. & & \\
\hline & CTRL & 35 & $100 \%$ & & & \\
\hline \multirow{4}{*}{$\begin{array}{l}\text { Dab (Limanda } \\
\text { limanda) }\end{array}$} & PULSE_CMPLT & 33 & $94 \%$ & \multirow{2}{*}{\} 1.0} & $93 \%$ & \multirow[t]{2}{*}{30.71} \\
\hline & CTRL & 48 & $94 \%$ & & $94 \%$ & \\
\hline & $\begin{array}{l}\text { PULSE_NO } \\
\text { NET }\end{array}$ & 45 & $100 \%$ & \multirow[t]{2}{*}{\} 0.22} & & \multirow{2}{*}{30.76} \\
\hline & CTRL & 41 & $95 \%$ & & & \\
\hline \multirow{4}{*}{$\begin{array}{l}\text { Solenette } \\
\text { (Buglossidium } \\
\text { luteum) }\end{array}$} & PULSE_CMPLT & 46 & $98 \%$ & \multirow{2}{*}{\} 1.0} & $97 \%$ & \multirow{2}{*}{30.76} \\
\hline & CTRL & 44 & $98 \%$ & & $98 \%$ & \\
\hline & $\begin{array}{l}\text { PULSE_NO } \\
\text { NET }\end{array}$ & 47 & $91 \%$ & \multirow[t]{2}{*}{30.67} & $91 \%$ & \multirow[t]{2}{*}{30.35} \\
\hline & CTRL & 42 & $95 \%$ & & $95 \%$ & \\
\hline \multirow{4}{*}{$\begin{array}{l}\text { Flying crab } \\
\text { (Liocarcinus } \\
\text { holsatus) }\end{array}$} & PULSE_CMPLT & 28 & $96 \%$ & \multirow{2}{*}{30.62} & & \\
\hline & CTRL & 39 & $91 \%$ & & & \\
\hline & $\begin{array}{l}\text { PULSE_NO } \\
\text { NET }\end{array}$ & 34 & $88 \%$ & \multirow[t]{2}{*}{\} 0.68} & $85 \%$ & \multirow[t]{2}{*}{30.30} \\
\hline & CTRL & 28 & $93 \%$ & & $93 \%$ & \\
\hline \multirow{4}{*}{$\left.\begin{array}{l}\text { Hermit crabs } \\
(\text { Paguroidea spp. })\end{array}\right)$} & PULSE_CMPLT & 30 & $100 \%$ & \multirow{2}{*}{ \}n.a. } & & \\
\hline & CTRL & 48 & $100 \%$ & & & \\
\hline & $\begin{array}{l}\text { PULSE_NO } \\
\text { NET }\end{array}$ & 42 & $100 \%$ & \}n.a. & & \\
\hline & CTRL & 30 & $100 \%$ & & & \\
\hline Brittle stars & PULSE_CMPLT & 52 & $90 \%$ & 30 & $87 \%$ & 30.59 \\
\hline (Ophiuroidea & CTRL & 49 & $88 \%$ & & $88 \%$ & \\
\hline spp. ) & $\begin{array}{l}\text { PULSE_NO } \\
\text { NET }\end{array}$ & 45 & $96 \%$ & \} 0.43 & $91 \%$ & 30.55 \\
\hline & CTRL & 47 & $89 \%$ & & $89 \%$ & \\
\hline
\end{tabular}




\subsubsection{Condition of fish}

Results for fish condition assessments and damage scores are presented in Table 7 and Table 8 sampled fish over the vitality index classes A, B, C and D was detected (Table 7). The fish sampled from the pulse trawl track made by the complete pulse trawl (PULSE_CMPLT) showed some deterioration of fish condition compared to its control treatment: the distribution of sampled fish over the vitality index classes A, B, C and D was not the same for plaice and solenette (Table 7). Although the data suggest a similar effect for dab, no significant difference could be detected for this species (Table 7). For dab we observed 'wounds' in all treatments with incidences ranging from 9.5 to $25 \%$ in the sampled fish. Without exception these wounds were skin ulcerations which are prevalent in wild common dab (Vercauteren et. al., 2018) which we consider to be unrelated to the current experimental treatments.

Table 7. Frequency of vitality index scores for plaice, dab and solenette collected from pulse trawl tracks made by a complete trawl (PULSE_CMPLT), pulse trawl tracks made by a pulse trawl without ground rope and net (PULSE_NO NET) and for unfished control areas (CTRL). Note that paired samples were obtained for treatment and controls; each treatment has its own controls. For pairs of treatment and control with a p-value $<0.05$ (Fisher's exact test) the distribution of sampled fish over the four vitality index classes is considered to differ significantly.

\begin{tabular}{|c|c|c|c|c|c|c|c|}
\hline Species & Treatment & $\begin{array}{l}\text { Total N } \\
\text { sampled }\end{array}$ & $A(\%)$ & B (\%) & C (\%) & D (\%) & $\begin{array}{l}\text { p-value } \\
\text { Fisher's } \\
\text { exact } \\
\text { test. }\end{array}$ \\
\hline \multirow[t]{4}{*}{ Plaice } & PULSE_CMPLT & 20 & 75 & 25 & 0 & 0 & \multirow{2}{*}{0.047} \\
\hline & CTRL & 20 & 95 & 0 & 5 & 0 & \\
\hline & PULSE_NO NET & 19 & 95 & 5 & 5 & 0 & \multirow{2}{*}{0.34} \\
\hline & CTRL & 20 & 80 & 20 & 0 & 0 & \\
\hline \multirow[t]{4}{*}{ Dab } & PULSE_CMPLT & 19 & 58 & 32 & 0 & 11 & \multirow{2}{*}{0.21} \\
\hline & CTRL & 20 & 80 & 20 & 0 & 0 & \\
\hline & PULSE_NO NET & 20 & 60 & 40 & 0 & 0 & \multirow{2}{*}{0.17} \\
\hline & CTRL & 20 & 80 & 20 & 0 & 0 & \\
\hline \multirow[t]{4}{*}{ Solenette } & PULSE_CMPLT & 20 & 75 & 20 & 0 & 5 & \multirow{2}{*}{\} 0.02} \\
\hline & CTRL & 20 & 100 & 0 & 0 & 0 & \\
\hline & PULSE_NO NET & 20 & 85 & 0 & 0 & 10 & \multirow{2}{*}{\} 1.0} \\
\hline & CTRL & 20 & 90 & 0 & 0 & 0 & \\
\hline
\end{tabular}


Table 8. Frequency of damage scores for plaice, dab and solenette collected from pulse trawl tracks made by a complete trawl (PULSE_CMPLT), pulse trawl tracks made by a pulse trawl without ground rope and net (PULSE_NO NET) and for unfished control areas (CTRL). Note that paired samples were obtained for treatment and controls; each treatment has its own controls.

\begin{tabular}{|c|c|c|c|c|c|c|c|c|}
\hline Species & Treatment & $\begin{array}{l}\text { Total N } \\
\text { sample } \\
\text { d }\end{array}$ & $\begin{array}{l}\text { Fins } \\
\text { split } \\
(\%)\end{array}$ & $\begin{array}{l}>50 \% \\
\text { scale } \\
\text { loss } \\
(\%)\end{array}$ & $\begin{array}{l}\text { Head } \\
\text { haemorrhage } \\
\text { s (\%) }\end{array}$ & $\begin{array}{l}\text { Hypodermic } \\
\text { haemorrhage } \\
\mathrm{s}(\%)\end{array}$ & $\begin{array}{l}\text { Intestine } \\
\mathrm{s}(\%)\end{array}$ & $\begin{array}{l}\text { Wound } \\
\mathrm{s}(\%)\end{array}$ \\
\hline \multirow[t]{4}{*}{ Plaice } & PULSE_CMPLT & 20 & 30 & 5 & 0 & 5 & 0 & 0 \\
\hline & CTRL & 20 & 35 & 10 & 0 & 20 & 0 & 0 \\
\hline & PULSE_NO NET & 19 & 16 & 0 & 0 & 0 & 0 & 0 \\
\hline & CTRL & 20 & 35 & 5 & 0 & 15 & 0 & 0 \\
\hline \multirow[t]{4}{*}{ Dab } & PULSE_CMPLT & 19 & 21 & 0 & 0 & 16 & 0 & 10 \\
\hline & CTRL & 20 & 25 & 0 & 0 & 25 & 0 & 15 \\
\hline & PULSE_NO NET & 20 & 15 & 5 & 0 & 10 & 0 & 25 \\
\hline & CTRL & 20 & 19 & 0 & 0 & 5 & 0 & 9.5 \\
\hline \multirow[t]{4}{*}{ Solenette } & PULSE_CMPLT & 20 & 0 & 5 & 0 & 5 & 0 & 0 \\
\hline & CTRL & 20 & 0 & 0 & 0 & 0 & 0 & 0 \\
\hline & PULSE_NO NET & 20 & 0 & 5 & 0 & 5 & 0 & 0 \\
\hline & CTRL & 20 & 0 & 0 & 0 & 0 & 0 & 0 \\
\hline
\end{tabular}

\subsubsection{Damages in invertebrates}

Condition of invertebrates was determined by scoring the presence of generic and species specific damages. The results are presented in Table 9. All hermit crabs we assessed were undamaged. Among flying crabs we observed missing limbs in 15 to $32 \%$ of the specimens where most of the brittle stars had lost at least part of one limb irrespective of the treatment. Treatment effects i.e. differences between treatments and their respective controls, were not detected (Fisher's exact tests, $p$-values per test not shown). Crushed carapaces or discs were not observed among flying crabs and brittle stars.

Table 9. Damage scores for flying crab, hermit crab and brittle star collected from pulse trawl tracks made by a complete trawl (PULSE_CMPLT), pulse trawl tracks made by a pulse trawl without ground rope and net (PULSE_NO NET) and for unfished control areas (CTRL). Note that paired samples were obtained for treatment and controls; each treatment has its own controls.

\begin{tabular}{|c|c|c|c|c|c|c|}
\hline Species & Treatment & $\begin{array}{l}\text { Total N } \\
\text { sampled }\end{array}$ & $\begin{array}{l}\text { Limbs } \\
\text { missing } \\
(\%)\end{array}$ & $\begin{array}{l}\text { Crushed } \\
\text { carapace or } \\
\text { disc }(\%)\end{array}$ & $\begin{array}{l}\text { Out of shell } \\
- \\
\text { undamaged } \\
(\%)\end{array}$ & $\begin{array}{l}\text { Out of shell } \\
\text { - damaged } \\
(\%)\end{array}$ \\
\hline \multirow[t]{4}{*}{ Flying crab } & PULSE_CMPLT & 20 & 15 & 0 & n.a. & n.a. \\
\hline & CTRL & 20 & 20 & 0 & n.a. & n.a. \\
\hline & PULSE_NO NET & 20 & 20 & 0 & n.a. & n.a. \\
\hline & CTRL & 19 & 32 & 0 & n.a. & n.a. \\
\hline \multirow[t]{4}{*}{ Hermit crab } & PULSE_CMPLT & 20 & n.a. & n.a. & 0 & 0 \\
\hline & CTRL & 20 & n.a. & n.a. & 0 & 0 \\
\hline & PULSE_NO NET & 21 & n.a. & n.a. & 0 & 0 \\
\hline & CTRL & 20 & n.a. & n.a. & 0 & 0 \\
\hline \multirow[t]{4}{*}{ Brittle star } & PULSE_CMPLT & 21 & 90 & 0 & n.a. & n.a. \\
\hline & CTRL & 20 & 85 & 0 & n.a. & n.a. \\
\hline & PULSE_NO NET & 20 & 85 & 0 & n.a. & n.a. \\
\hline & CTRL & 20 & 65 & 0 & n.a. & n.a. \\
\hline
\end{tabular}




\subsection{Catch compositions}

\subsubsection{Samples collected by the shrimp trawler}

Samples were defined as the total catch by a single tow by one of the two shrimp trawls.

Consequently, two samples were collected for each tow. The species composition of each sample is presented in Table 10. The three fish and three invertebrate species that were sampled dominated all samples (hence their selection for sampling). Next to these six species, lesser weevers (Echiichthys vipera) were present in all samples. The category 'Other fish' grouped all fish species other than the specified species. Total catch masses varied from 8 to $18.5 \mathrm{~kg}$. The tows in the track of the pulse trawls consistently yielded the higher total catch masses than their controls (differences were not tested for significance). In case of the complete pulse trawl we attribute this to the smoothening of the sea floor by this trawl, as observed on our underwater video footage, this may increase catch efficiency of the footrope. Other reasons may be related to opportunistic scavenger aggregations on trawl disturbed sea bottoms. Extrapolated to a conventional tow duration of two hours, total catch masses ranged from approximately 90 to $220 \mathrm{~kg}$ per trawl.

Table 10. Species composition per sample. Unless stated otherwise the biomass $(\mathrm{kg})$ per species is given.

\begin{tabular}{|c|c|c|c|c|c|c|c|c|}
\hline \multirow{2}{*}{\begin{tabular}{|l} 
Tow/Sample \\
Treatment
\end{tabular}} & \multicolumn{2}{|l|}{5} & \multicolumn{2}{|c|}{6} & \multicolumn{2}{|c|}{7} & \multicolumn{2}{|l|}{8} \\
\hline & PULS_CMPLT & CTRL & $\begin{array}{c}\text { PULS_NO } \\
\text { NET }\end{array}$ & CTRL & $\begin{array}{c}\text { PULS_N } \\
\text { O NET }\end{array}$ & CTRL & \begin{tabular}{|c|} 
PULS_CMPL \\
$T$
\end{tabular} & CTRL \\
\hline Plaice (Pleuronectus platessa) & 2.5 & 1.63 & 1.44 & 0.96 & 0.58 & 0.58 & 1.06 & 058 \\
\hline Dab (Limanda limanda) & 7.49 & 5.86 & 7.78 & 5.57 & 3.94 & 2.78 & 4.51 & 2.59 \\
\hline Solenette & 1.06 & 0.77 & 0.48 & 0.48 & 0.48 & 0.38 & 0.48 & 0.48 \\
\hline $\begin{array}{l}\text { Lesser weever (Echiichthys } \\
\text { vipera) }\end{array}$ & 1.63 & 1.73 & 0.48 & 0.86 & 0.58 & 0.86 & 0.29 & 0.67 \\
\hline Sole (Solea solea) & - & - & 1.54 & 1.06 & - & - & - & - \\
\hline Other fish & 1.06 & 1.34 & 0.77 & 1.06 & 0 & 0.58 & 0.72 & 0.86 \\
\hline Flying crab (Liocarcinus holsatus) & 1.54 & 0.14 & 0.38 & 0.48 & 0.48 & 0.19 & 0.38 & 0.48 \\
\hline Hermit crab (Paguroidea spp.) & 0.58 & 0.58 & 0.48 & 0.48 & 0.19 & 0.29 & 0.38 & 0.38 \\
\hline Brittle stars (Ophiuroidea spp.) & 0.86 & 1.15 & 1.54 & 1.06 & 1.44 & 1.25 & 1.15 & 0.77 \\
\hline Jelly fish & 0.07 & 1.34 & 0.1 & - & - & - & 0.67 & 0.58 \\
\hline Brown crab (Cancer pagurus) & - & 0.86 & - & - & - & - & - & - \\
\hline Sea potato (Echinocardium spp) & - & 0.11 & 0.1 & - & - & - & - & 0.10 \\
\hline Debris & 1.73 & 0.77 & 0.67 & 0.58 & 0.58 & 0.48 & 1.54 & 0.48 \\
\hline Total & 18.5 & 17.0 & 15.8 & 12.6 & 8.3 & 7.4 & 11.2 & 8.1 \\
\hline
\end{tabular}




\subsubsection{Catches by the pulse trawler}

The amounts of marketable sole $(>24 \mathrm{~cm})$, plaice $(>27 \mathrm{~cm})$ and other fish were recorded by the skipper of pulse trawler for each tow aimed at creating pulse trawl tracks for the experiment. Since the net and ground rope had been removed from the port side trawl to create the PULSE_NO NET treatment, no fish were caught by this trawl. Total amounts of sole, plaice and other marketable fish are presented per tow in Table 11. Estimates of total sole catches by extrapolation to double trawls and regular commercial towing times of 2 hours range from 16 to $30 \mathrm{~kg}$.

Table 11. Amounts $(\mathrm{kg})$ of marketable fish caught by the pulse trawler whilst making the pulse trawl tracks.

\begin{tabular}{|c|c|c|c|c|}
\hline Tow & 5 & 6 & 7 & 8 \\
\hline Tow duration (min) & 45 & 35 & 40 & 45 \\
\hline Sole (Solea solea) $>24 \mathrm{~cm}$ & 3 & 4 & 5 & 4 \\
\hline Plaice (Pleuronectus platessa) $>27 \mathrm{~cm}$ & 3 & 4 & 3 & 3 \\
\hline Other marketable fish & 25 & 35 & 20 & 20 \\
\hline Estimated sole catches regular tows1) & 16 & 27 & 30 & 21 \\
\hline
\end{tabular}

1) Proportionally extrapolated to a double trawl and a tow duration of $120 \mathrm{~min}$. 


\section{Discussion}

\subsection{General}

This pilot study was conducted because of concerns that a passing pulse trawler causes mass mortality among benthic biota in its trawl track. These concerns are relevant in the assessment of impacts of pulse trawl fisheries and were not previously investigated in situ. Since effective sampling of biota from a pulse trawl track to assess their condition meets various methodological challenges, the current pilot study aimed at method development. The specific the objectives of this method development included: 1. Investigate whether it is possible to detect the track of pulse trawls on the sea floor using side-scan WASSP sonar, 2. Test whether it is possible to deploy a shrimp trawl inside the pulse trawl track and sample benthic organisms from the track, 3. To confirm the deployment of the shrimp trawl in the pulse trawl track by underwater video observations, 4. To assess the species composition of samples collection in pulse trawl tracks, 5. To test methods for assessment of the condition of sampled organisms. In addition to method development, this pilot study aimed for a first assessment of the condition of fish and invertebrates in pulse trawl tracks within one hour after pulse trawls passage.

\subsection{Sampling of biota from pulse trawl tracks}

Clearly it is very difficult to collect biota samples exclusively from a pulse trawl track. At sea the recently trawled pulse track could not be detected on the sea floor with the WASSP sonar of the shrimp trawler. Therefore the shrimp trawler first had to follow the pulse trawler to record the pulse trawl track using the WASSP sonar image of pulse trawls on the seafloor. These recording were then used to deploy and maintain the shrimp trawl inside the pulse trawl track. Our observations with camera's on the shrimp trawl confirmed that the skipper was able to deploy the shrimp trawl inside the desired pulse trawl track, at least for part of the time, and that it is thus possible to collect biota samples from that track. However, our camera observations also revealed that on the sea floor the shrimp trawl may move in and out of the pulse trawl track. For the four sampling tows we considered successful, the area swept inside the pulse trawl track was estimated to range from $43 \%$ to $80 \%$ of the total swept area. In practice, it seems inevitable that part of the area swept by the sampling trawl lies outside the pulse trawl track it aims for. Consequently the samples originate only partly from the pulse trawl track, which was taken into account in the analysis of the data. In the video analysis the slits drawn in the seafloor by the pulse modules of the pulse trawl without net and ground rope, allowed us to accurately position the shrimp trawl on the seafloor and thereby reconstruct its path relative to the pulse trawl track. The area swept inside the pulse trawl track could then be accurately determined. As these slits of the pulse trawl track by the complete pulse trawl are invisible, the location of the shrimp trawl could only be estimated from the slits drawn by the chains attached to the extremities of the seawings. As a result the reconstructions of its path relative to the pulse trawl track as well as the estimates for the areas swept inside the pulse trawl tracks are less accurate. Since direct survival did not differ between the pulse trawl tracks and controls, this lower accuracy does not affect our conclusions. However, for future experiments it is recommended to collect more information on the shrimp trawl's position on the seafloor in order to accurately reconstruct its path and the area swept inside the pulse trawl tracks. We expect that this can be achieved by mounting a third camera centrally on the beam of the shrimp trawl.

The shrimp trawl in this experiment was equipped with a modified ground rope to collect as much specimens from the seafloor as possible. It should be noted however that we probably sampled exclusively from the seafloor as is reflected by the species composition of our samples. Any biota residing in the seafloor did not appear in our samples and we therefore have no data on direct mortality among those biota as a result of a passing pulse trawl. The absence of infauna in our samples also shows that pulse field exposure does not stimulate infauna to immediately surface from the sediment. 


\subsection{Experimental design}

Collecting paired samples for treatment \& control from two trawls in a single tow worked well in practice. As paired sampling under comparable conditions and from the same fishing ground for both samples reduces variation, it is recommended to use this sampling strategy in further research. It should be mentioned that more advanced statistical methods than currently used are required to utilize the benefits from paired sampling. Since no clear difference between the direct survival of fish and invertebrates could be observed for the complete pulse trawl and pulse trawl without net and ground rope treatments, the added value of the latter treatments seems limited for the species tested. The inclusion of this treatment in future experiments should therefore be reconsidered.

In the current pilot the areas swept inside the pulse trawl track was conservatively estimated to range from $43 \%$ to $80 \%$. It seems clear that sampling only $(100 \%)$ inside the pulse trawl track is very hard to achieve and an unrealistic condition for accepting the data. Given our experience in the current pilot, it seems more realistic to set the threshold for considering the sampling of a pulse trawl track as successful at $50 \%$ inside the track. Underwater video recording as applied in the current study is required to confirm sampling inside pulse trawl tracks and estimate the proportions of swept area inside and outside the track during a sampling tow. An extra camera in the middle of the beam of the shrimp trawl, in addition to the cameras at the two extremities of the beam, would allow for more accurate estimates of the swept area inside the pulse trawl track. Ideally the statistical model used to test for differences between the (paired) treatment and control samples corrects for the extent to which the sample was actually collected inside the pulse trawl track.

\subsection{Direct survival of fish}

Of the total of eight sampling tows conducted in the current pilot study, we considered four tows as successful based on the estimates of swept area inside the pulse trawl tracks: two tows for the pulse trawl tracks made by the complete pulse trawl (PULSE_CMPLT) and two tows for the pulse trawl tracks made by the pulse trawl without ground rope and net (PULSE_NO NET). Overall the direct survival among the three fish species tested, plaice, dab and solenette, ranged from 91 to 100 .

In a few cases the direct survival in control tows was higher than observed for the related pulse trawl tracks. In these cases we corrected the direct survival for the pulse trawl track for the actual area swept inside the pulse trawl track during the sampling tow. This correction assumed that the appearance of biota originating from inside and outside the pulse trawl tracks was proportional to the areas swept in and outside the pulse trawl track during the sampling tows. The correction also assumed that conditions of the biota collected outside the pulse trawl track the control tows were equal. Although correction increased the difference between the direct survival estimates for treatment and control, no significant differences in direct survival were detected.

The direct survival observed in the current study is comparable to the direct survival of plaice and sole sampled from two hour tows by commercial pulse trawlers in our discards survival studies (Schram and Molenaar, 2018). However, in that study delayed mortality, mainly occurring during the first five days post capture, ultimately resulted delayed discards survival that was much lower than the direct survival. We attributed this delayed mortality to the generally poor condition of the fish due to the catching process, which was reflected in the fish condition scoring. Indeed, we found a strong relation between fish condition directly after landing on deck and the long-term chances of survival of individual fish. In the current study we used the same method to determine the condition of individual fish. In contrast to our discards survival studies, most fish in the current study were in excellent condition directly after landing on deck. Condition of the fish in the samples of the current study may be affected by impact of exposure to the pulse fields, mechanical impacts of the passing pulse trawl and footrope, retention in and escaping from the cod-end and mechanical impact of the catching process with the shrimp trawl. To keep the latter to a minimum, towing time to collect the samples with the shrimp trawls was kept very short at 10-12 minutes. Given our observation that fish were generally in excellent condition, in particular in the treatment with the ground rope and net removed suggests that the exposure to pulse stimulus does not reduce the short-term survivorship. In addition, 
it is highly likely that as for the excellent condition of the fish, not only the direct survival but also the delayed survival is very high. Dedicated survival studies in which sampled fish are kept in captivity to monitor their long-term survival are needed to corroborate this notion.

The fish sampled from the pulse trawl track made by the complete pulse trawl showed some impact on fish condition compared to its control treatment. Although we did not statistically compare fish condition between the two pulse trawl track treatments, it seems that fish from the track made by the complete pulse trawl were in a slightly poorer condition than the fish from the track made by the pulse trawl without ground rope and net. We'd attribute this difference to a higher mechanical impact of the complete pulse trawl; the pulse trawl running over the organisms or being captured in the trawl and escape through the mesh openings. The slightly poorer condition did not result in a higher direct mortality among the fish sampled from the pulse trawl track made by the complete pulse trawl.

\subsection{Direct survival of invertebrates}

Similar to our observations on fish, direct survival among the tested invertebrate species was high and ranged from $88 \%$ to $100 \%$ across treatments. Direct survival did not differ between either of the two pulse trawl track treatments and their respective controls. This absence of a treatment effect remained unaffected after correcting some of the direct survival observations for the actual areas swept inside the pulse trawl tracks. Similar to the tested fish, we consider it highly likely that the direct survival of the invertebrates does not differ between the two pulse trawl track treatments, although this was not tested directly. To what extent this high direct survival is indicative for a high long-term survival is unknown. Dedicated survival studies similar to those described for fish are required to establish long-term survival. However, given the observed condition of the invertebrates it seems not likely that long-term survival is much lower than direct survival.

Condition of hermit crabs was assessed by checking individuals for non-specified damage while being in or out of its shell. All assessed hermits crabs were found to be undamaged. This either suggests that hermit crabs are very resilient to the impacts inflicted by the passing pulse trawl and catching by the shrimp trawl, or that our condition assessment criteria lack sensitivity to detect impacts by the pulse and shrimp trawl.

Condition of flying crabs and brittle stars was assessed by checking individuals for crushed carapaces (crabs) or discs (brittle stars) and for (partly) missing limbs. None of the assessed crabs and brittle stars was found to be crushed, which indicates that the mechanical impacts of the passing pulse trawl and capture by the shrimp trawl are probably limited. Missing limbs were observed across treatments in both invertebrate species. Although we did not test for treatment effects, its seems unlikely that in flying crabs the loss of limbs is caused by the pulse trawl as we consistently found a higher incidence of missing limbs in the control treatments. Since we could not determine whether the loss of a limb was recent, we cannot attribute loss of limbs to impacts of the pulse or shrimp trawl nor exclude such impacts. With an incidence of $65 \%$ to $90 \%$ across treatments the majority brittle stars showed some degree of missing limbs. This may be a reflection of the sensitivity of this invertebrate to the mechanical impacts of the pulse trawl or the shrimp trawl. However, some impact of the pulse trawl cannot be entirely excluded based on our current observations. In contrast to flying crab, we consistently observed a higher incidence of missing limbs in the pulse trawl track treatments. More observations are needed to establish the presence of such an effect. 


\section{$5 \quad$ Conclusions and recommendations}

\subsection{Methodology}

We conclude that with the right equipment, skilled skippers, a calm sea and no wind it is possible to sample biota from a track immediately after trawling by a pulse trawler. However, it is very difficult to sample exclusively from a pulse trawl track; it is inevitable that part of the area swept by a sampling tow lies outside the pulse trawl track. Paired sampling of the pulse trawl track and an unfished control area by using double trawls is recommended. Statistical analysis should take into account paired sampling as well as correct for the areas swept outside the pulse trawl track during sampling tows.

In its current set-up, the current study is only suitable to assess direct mortality caused by a passing pulse trawler. As time passes, it becomes increasingly difficult to detect pulse trawl tracks on the seafloor and thereby successful sampling inside these tracks. In addition, over time water currents may result in displacement of (dead) biota either in or out of the pulse trawl track and scavengers may be attracted to the track. Jointly taken, with increasing time between the passage of the pulse trawler and the sampling of its trawl track, accurate and representative sampling becomes increasingly difficult. Assessment of mortality other than direct mortality thus requires other methods. Long-term survival of specimens collected directly after the passage of a pulse trawler can be assessed by keeping them captivity until mortality stabilizes.

We recommend to equip the sampling trawl with more cameras for a more accurate reconstruction of the path of sampling trawls relative to the pulse trawl tracks.

\subsection{Mass mortality in the wake of a pulse trawler}

This pilot study was conducted because of concerns that a passing pulse trawler causes mass mortality among benthic biota in its trawl track. The number of observations per species was limited in this pilot study and samples were only partly collected inside the pulse trawl tracks. Despite these limitations, any direct mass mortality caused by a passing pulse trawler would have been recorded in the current study, not only for the systematically observed species but also for other species in the samples. Our study thus did not find any evidence of direct mortality among plaice, dab, solenette, flying crab and brittle stars.

In this study we sampled species that dwell on the sea floor while species that live in the sea bottom are, up to a certain depth, also exposed to passing pulse fields. Their fate was not established in this pilot study. We therefore recommend to repeat the current experiment in other habitats and with the use of other sampling devices in order to collect a wider variety of species. 


\section{Acknowledgements}

This project was funded by the Dutch Ministry for Agriculture, Nature conservation and Food safety (contract BO-43-023.02.032 Directe effecten pulsvisserij) and by the Dutch "Pulse fund", a fund to which all pulse fishers contribute through their sector organisations.

This project would not have been possible without the following contributors. All stakeholders, both private fishermen and stakeholder organisations participating in the stakeholder consultation preceding the research pilot at sea. The "Nederlandse Visserbond" and "VisNed" for arranging for the participating vessels and the financial contribution from the "Pulse Fund". The skippers, owners and crews of the participating pulse trawler SC 25 Evert Snoek and shrimp/nephrops trawler WR 189 Grietje. Cees van Eekelen sr. for the design and construction of the ground ropes for the shrimp trawl. 


\section{Quality Assurance}

Wageningen Marine Research utilises an ISO 9001:2015 certified quality management system. This certificate is valid until 15 December 2021. The organisation has been certified since 27 February 2001. The certification was issued by DNV GL. 


\section{References}

Bergman, M.J.N., Van Santbrink, J.W., 2000. Mortality in megafaunal benthic populations caused by trawl fisheries on the Dutch continental shelf in the North Sea in 1994. ICES Journal of Marine Science 57 (5), p1321-1331.

Bloom. 2018. Electric 'pulse' fishing: why it should be banned. http://www.bloomassociation.org/en/wp-content/uploads/2018/01/electric-fishingadvocacy.pdf.

Hiddink, J. G., Jennings, S., Sciberras, M., Szostek, C. L., Hughes, K. M., Ellis, N., Rijnsdorp, A. D., et al. 2017. Global analysis of depletion and recovery of seabed biota after bottom trawling disturbance. Proceedings of the National Academy of Sciences, 114: 8301-8306.

Quirijns, F.J., Steins, N.A., Steenbergen, J., Rijnsdorp, A.D. 2018. Recommendations for additional research into pulse-trawl fisheries. Wageningen Marine Research reportC106/18.

Sciberras, M., Hiddink, J., Jennings, S., Szostek, C. L., Hughes, K. M., Kneafsey, B., Clarke, L., et al. 2018. Response of benthic fauna to experimental bottom fishing: a global meta-analysis. Fish and Fisheries, 19: 698-715.

Schram, E., Molenaar, P. 2018. Discards survival probabilities of flatfish and rays in North Sea pulsetrawl fisheries. Wageningen Marine Research Report C037/17.

Smaal, A. C., and Brummelhuis, E. 2005. Explorative studies of the impact of an electric fishing field on macrobenthos. RIVO C089/05 15p. 15 pp.

Soetaert, M. , Decostere, A. , Polet, H. , Verschueren, B. and Chiers, K. 2015a. Electrotrawling: a promising alternative fishing technique warranting further exploration. Fish Fish, 16: 104-124.

Soetaert, M., Chiers, K., Duchateau, L., Polet, H., Verschueren, B., and Decostere, A. 2015b. Determining the safety range of electrical pulses for two benthic invertebrates: brown shrimp (Crangon crangon L.) and ragworm (Alitta virens S.). Ices Journal of Marine Science, 72: 973980.Soetaert, M., Chiers, K., Duchateau, L., Polet, H., Verschueren, B., and Decostere, A. 2015b. Determining the safety range of electrical pulses for two benthic invertebrates: brown shrimp (Crangon crangon L.) and ragworm (Alitta virens S.). Ices Journal of Marine Science, 72: $973-980$.

Van der Reijden, K. J., Molenaar, P., Chen, C., Uhlmann, S.S., Goudswaard, P.C. Van Marlen, B. 2017. Survival of undersized plaice (Pleuronectes platessa), sole (Solea solea), and dab (Limanda limanda) in North Sea pulse-trawl fisheries. ICES Journal of Marine Science 74(6), 1672-1680.

Vercauteren, M, De Swaef, E, Declercq, A, et al. 2018. First isolation of Vibrio tapetis and an atypical strain of Aeromonas salmonicida from skin ulcerations in common dab (Limanda limanda) in the North Sea. J Fish Dis. 41: 329- 335. 


\section{Justification}

Report C097/19

Project Number: 4318200053

The scientific quality of this report has been peer reviewed by a colleague scientist and a member of the Management Team of Wageningen Marine Research

Approved: $\quad$ Adriaan Rijnsdorp

Researcher

Signature:

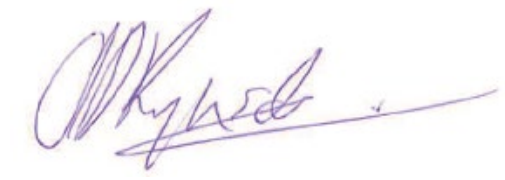

Date:

22 October 2019

Approved: Jakob Asjes

Manager Integration

Signature:

Date:

22 October 2019 


\section{Annex 1 Stakeholder consultation (in Dutch)}

Stakeholder consultatie i.v.m. onderzoekpilot "Directe effecten pulsvisserij bodemleven" (BO-43-023.02-032).

Datum \& tijd: 25 januari 2019, 13:00 - 15:00.

Deelnemers

\begin{tabular}{|l|l|}
\hline Naam & Organisatie / Bedrijf \\
\hline Willem de Waal & C-Life \\
\hline Andries Visser Sr. & C-Life \\
\hline David Vertegaal & C-Life \\
\hline Henk Buitjes & Sportvisserij Nederland \\
\hline Matthijs vd Ploeg & ZK37 \\
\hline Arjan Heinen & De Rousant \\
\hline Justin Belleman & Netviswerk \\
\hline Nathalie Steins & IJM52 \\
\hline Pieke Molenaar & Wageningen Marine Research \\
\hline Edward Schram & Wageningen Marine Research \\
\hline
\end{tabular}

\section{Agenda}

\section{Welkom \& opening}

Nathalie Steins opent de vergadering en geeft een toelichting op de aanleiding en het doel van de bijeenkomst:

- De kleinschalige visserijen uiten al langere tijd zorgen over het effect van pulsvisserij op de visstand in de NL kustwateren. Een van de zorgen/observaties is dat door het passeren van een pulstuig sterfte optreedt onder bodemdieren. LNV heeft daarom WMR de opdracht gegeven een pilotstudie te doen naar dit mogelijke effect van pulsvisserij.

- Voor een goede opzet van de pilotstudie acht WMR het belangrijk om de zorgen vanuit de kleinschalige visserijen mee te nemen in de onderzoeksopzet.

- Het doel van de bijeenkomst is daarom 1. Belanghebbenden te informeren over het aanstaande onderzoek naar sterfte van dieren in het pulsspoor 2 . Belanghebbenden de gelegenheid te bieden om hun zorgen en ervaringen m.b.t. dit vermeende effect van pulsvisserij naar voren te brengen zodat deze door WMR genomen kunnen worden in de onderzoeksopzet, 3 . Onderling overeenstemming te bereiken over de gewenste opzet (diverse opties worden gepresenteerd en toegelicht). 4. Afspraken te maken over eventuele betrokkenheid van belanghebbenden bij de uitvoering van het onderzoek in de rol van waarnemers. 


\section{Voorstel rondje}

Alle aanwezigen stellen zichzelf voor. Daarbij worden in het bijzonder nog de volgende punten naar voren gebracht:

Gevraagd wordt of in de Verburg \& Boddeke visie (bijlage) aanknopingspunten zitten voor het onderzoek. De puls heeft als Carola (Schouten) haar hand in de pulsbak houdt geen effect, maar een kabeljauw kan z'n rug breken. Pulsschepen hebben volgens een aantal aanwezigen een knop om de stroom hoger te zetten. Als er wetenschappers aan boord zijn, wordt de knop teruggedraaid. Pulskotters gebruiken in vergelijking met een wekkervisser een zelfde hoeveelheid brandstof voor een dubbele hoeveelheid vangst. Een andere aanwezige vult aan dat oud vissers hebben verklaard dat er wel een knop is.

Een andere vraag is hoe organismen reageren op verschillende veldsterktes? Klein pulsje heeft waarschijnlijk geen effect, maar als de visserman de knop omhoog draait heeft het wel effect. Garnalenvissers waren eerst tegen, nu gematigd voor omdat het visserijproces makkelijker en goedkoper kan.

\section{Presentatie onderzoeksopzet}

Edward Schram presenteert de voorlopige aanpak van het onderzoek (Presentatie in de bijlage). De aanpak van het onderzoek op hoofdlijnen bestaat uit het verzamelen van monsters met een fijnmazig net (garnalentuig) in het kielzog van een pulskotter en ook daarbuiten ter vergelijking. De pulskotter vist daarbij in opdracht van WMR. Er zijn verschillende opties voor de visserij waarvan in het kielzog monsters genomen kunnen worden. Elke optie leidt tot een ander resultaat; heeft specifieke voor en nadelen. In de pilot kan niet alles gedaan worden. Daarom moeten keuzes gemaakt worden. De gepresenteerde opties zijn:

Tabel 1. Opties voor te bemonsteren visserijen

\begin{tabular}{|c|c|c|c|}
\hline $\mathrm{Nr}$. & Te bemonsteren visserij & Voordeel & Nadeel \\
\hline 1 & Pulstuig - stroom aan & $\begin{array}{l}\text { Pulsvisserij zoals deze in de praktijk } \\
\text { plaatsvindt. De resultaten van het } \\
\text { onderzoek zeggen iets over de } \\
\text { praktijk. }\end{array}$ & $\begin{array}{l}\text { Als er een effect gevonden } \\
\text { wordt, is dit een effect van het } \\
\text { pulstuig als geheel. Er kan geen } \\
\text { onderscheid gemaakt worden } \\
\text { tussen } 1 . \text { Het effect van het } \\
\text { pulsveld } 2 \text {. Het effect van de } \\
\text { onderpees en } 3 \text {. Het effect van } \\
\text { het net. }\end{array}$ \\
\hline 2 & Pulstuig - stroom uit & $\begin{array}{l}\text { In combinatie met bemonstering van } \\
\text { een pulstuig met de stoom aan (nr. } \\
\text { 1) kan iets gezegd worden van het } \\
\text { mechanische effect (onderpees + } \\
\text { net) en het elektrische effect } \\
\text { (pulsveld) }\end{array}$ & $\begin{array}{l}\text { Levert geen informatie op over } \\
\text { het pulstuig zoals dat in de } \\
\text { praktijk gebruikt wordt - moet } \\
\text { daarom gecombineerd worden } \\
\text { met } \mathrm{Nr} 1 \text {. }\end{array}$ \\
\hline 3 & $\begin{array}{l}\text { Boomkor met } \\
\text { wekkerkettingen }\end{array}$ & $\begin{array}{l}\text { In combinatie met bemonstering van } \\
\text { een pulstuig met de stoom aan (nr. } \\
\text { 1) kan iets gezegd worden over het } \\
\text { verschil tussen evt. effecten van } \\
\text { pulstuigen en wekkerkettingtuigen }\end{array}$ & $\begin{array}{l}\text { Het levert alleen informatie op } \\
\text { over de evt. effecten van de } \\
\text { vistuigen als geheel; }\end{array}$ \\
\hline 4 & $\begin{array}{l}\text { Pulstuig-stroom aan - } \\
\text { zonder net }\end{array}$ & $\begin{array}{l}\text { Evt. effecten zijn alleen toe te } \\
\text { schrijven aan het pulsveld; } \\
\text { mechanische effecten van onderpees } \\
\text { en net worden geëlimineerd. }\end{array}$ & $\begin{array}{l}\text { Levert geen informatie op over } \\
\text { het pulstuig zoals dat in de } \\
\text { praktijk gebruikt wordt - moet } \\
\text { daarom gecombineerd worden } \\
\text { met } \mathrm{Nr} 1 \text {. }\end{array}$ \\
\hline
\end{tabular}

Benadrukt werd dat het onderzoek een pilot betreft. Dit betekent dat de omvang van het onderzoek te klein is om definitieve uitspraken te doen over de vraag of het passeren van een pulstuig leidt tot sterfte onder dieren die aan het pulsveld worden blootgesteld. Daarvoor is uitgebreider vervolg onderzoek. De doelen van de pilot zijn 1. Testen en ontwikkelen van methoden om directe sterfte door pulsvisserij vast te stellen en 2 . Het verzamelen van de eerste indicatieve meetgegevens.

Concrete vragen aan de deelnemers m.b.t. de opzet van het onderzoek zijn:

- Welke dieren moeten zeker in het onderzoek worden meegenomen?

- Hoe lang na het passeren van de pulskotter moeten monsters genomen worden?

- Waar op zee, op welke type bodem moet het onderzoek uitgevoerd worden. 
Vragen en opmerkingen n.a.v. de presentatie:

Er zijn volgens een van de aanwezigen twee onderzoeksmethoden 1. Aan de schipper melden dat je achter hem aan vist; 2 . Na een week een puls bestek afvissen en kijken wat er ligt. Bij de tweede optie ben je zekerder dat de blootstelling aan het pulsveld overeenkomt met de pulsinstellingen die de vissers gebruiken.

$\Rightarrow$ Reactie WMR: we moeten inderdaad zeker weten dat het pulstuig aan staat en ingesteld is op de instellingen zoals in de praktijk wordt gebruikt. Daarom is het belangrijk dat er een onafhankelijke en deskundige waarnemer mee gaat aan boord van de pulskotter.

$\Rightarrow$ Reactie WMR: het bemonsteren van een bestek dat daarvoor door een pulskotter is bevist (op basis van AIS data bijv.) is mogelijk een optie voor het evt. vervolgonderzoek. Het probleem is echter het onderscheid maken tussen gevangen dode discards en effecten van het pulstuig op zich zelf. Echter voor de huidige pilotstudie is gekozen voor het direct achter een pulskotter aan vissen omdat er dan minder onzekerheden zijn over de positie van het spoor en het effect van de tijd (stroming, predatoren) op hetgeen in het spoor wordt aangetroffen. De voorkeur gaat uit naar direct in het spoor vissen waarbij men er zeker van is dat er geen dode discards gevangen kunnen worden

Alle aanwezigen zijn het er mee eens, niet de dode/beschadigde discards opvissen.

Een van de vissers geeft aan dat de locatie onder de kust moet zijn. Als er op een locatie op dat moment niets zit moet je het onderzoek daar niet uitvoeren.

Een visser stelt voor om voor het garnalentuig een extra zware onderpees te gebruiken, om te zorgen dat je alles opschept met het garnalentuig; mogelijk een ketting er voor.

$\Rightarrow$ Reactie WMR: onderpees wordt aangepast (1 dichte pees zoals gebruikt in de visserij op Noorse Kreeft).

Met betrekking tot optie 1 voor het bemonsteren zegt een van de vissers dat de puls er voor zorgt dat garnaal immobiel op de bodem ligt, en dat het dan de onderpees van het pulstuig is die de garnaal beschadigt. Als je met alleen modules vist (pulstuig zonder net) zal je beschadiging van de garnalen niet waarnemen. Als je dat wilt meten hoeft het net niet achter het pulstuig maar er moet daarom wel een onderpees bevestigd worden.

$\Rightarrow$ Reactie WMR: juist omdat de onderpees ook beschadiging van dieren kan veroorzaken, laten we deze ook weg. Op die manieren meten we alleen het effect van het pulsveld.

Een van de aanwezigen maakt de vergelijk met 'tafeltje dekje', niet te lang wachten met achter het pulstuig aan vissen want dan is alles dat dood is gegaan al opgegeten. De kreet van de kleinschalige visser is dat het vroeger voordelig was om achter de wekkers aan te gaan met staand want, dan ving je meer. Ook vanuit de garnalenvloot zijn er opmerkingen dat vroeger toen de Bokkers met kettingen visten, de grote garnalen op het net zaten of tussen de mazen van de bovenzijde van het net. Met de puls is dat niet meer zo, wel ziet men in de zuid dode garnalen achter een pulskotter. Een van de vissers vat het als volgt samen: waarom vang je na een wekker wel goed en na een pulskotter niet? Dit is een kernvraag!

Op de vraag van WMR wat de kleinschalige vissers zien in het pulsspoor antwoordt men: dode krabben, dode scharren .Ook is er geen bot meer te vinden in de 12 mijl. Ook zien ze weinig kabeljauw, bot, wijting in hun visgebied (kustzone). Komt dit door puls?

De vissers vragen zich ook af of de verschillende puls instellingen verschillende effecten hebben?

$\Rightarrow$ Reactie WMR: dit is een relevante vraag maar kan binnen de tijd en de middelen van pilotstudie niet beantwoord worden.

\section{Uit de discussie komt de volgende wensenlijst van de vissers naar voren: Naar welke soorten moeten we kijken:}
1. Garnaal
2. Schar
3. Bot
4. Kabeljauw
5. Wijting
6. Zeester -> aaseter komt op vis af
7. Alikruik
8. krabben 

9. Scheermessen
10. Zagers
11. Zeepieren
12. Puitaal

Hoe dicht achter pulskotter:

- 50 meter

- $\quad$ direct

- 200 meter

$\Rightarrow \quad \mathrm{Na}$ discussie over bovengenoemde mogelijkheden is de consensus dat de bemonstering direct achter de pulskotter zal gebeuren.

\section{Bodemtype / locatie op zee:}

Binnen de 12 mijl kan de pulskotter niet vissen volgens een van de vissers omdat er te veel zeesterren liggen.

$\Rightarrow$ Afgesproken wordt dat tegen de 12 mijl waar de tong in het vroege voorjaar zit zal worden gevist-> 10.5-11 mijl uit de kust. In dit gebied is ook minimaal pulsvisserij inspanning en dus goed referentiegebied in de buurt.

\section{Opties voor bemonstering:}

De deelnemers worden het er over eens dat het pulstuig (stroom aan) en het pulstuig zonder net gebruikt moeten worden in het onderzoek.

$\Rightarrow$ Reactie WMR: dit gaan we doen onder het voorbehoud dat de schipper van de pulskotter bereid is om aan een kant van zijn schip zonder net te vissen (en aan de andere kant met net).

\section{Waarnemersrol:}

De groep zou graag deelnemers afvaardigen als waarnemers aan boord van de deelnemende pulskotter en de garnalen kotter.

WMR zal zich daarvoor inzetten (maximaal 1 waarnemer per kotter), maar kan geen garanties geven omdat de schippers bepalen wie er wel en niet aan boord komen. Van de waarnemer aan boord van het volg-schip wordt verwacht dat hij mee moeten helpen met het uitvoeren van de bemonstering. Afgesproken wordt dat WMR de deelnemers op de hoogte houdt van de planning van het experiment en dat de groep onderling besluit wie als waarnemers zullen optreden.

\section{Overige zorgen \& vragen in relatie tot pulsvisserij}

Deze komen niet aan de orde in het huidige proefproject, maar worden wel genoteerd.

Wordt grote vis verjaagd door puls!? Of door kotters? Vissers menen te zien dat de vis verstoord en verjaagd wordt door het passeren van een pulskotter en dat alle (grote) vis uit de Zuidelijke Noordzee weg trekt door de aanwezigheid van pulskotters. Wrak: camera's - pulskotter \& wekkerkotter langs vissen, wat doet te vis!?

\section{Bijlagen}

1. Deelnemerslijst

2. Stuk van Bodeke ingebracht door een van de vissers

3. Presentatie WMR 


\section{Annex 2 Photos illustrating the pilot experiment}

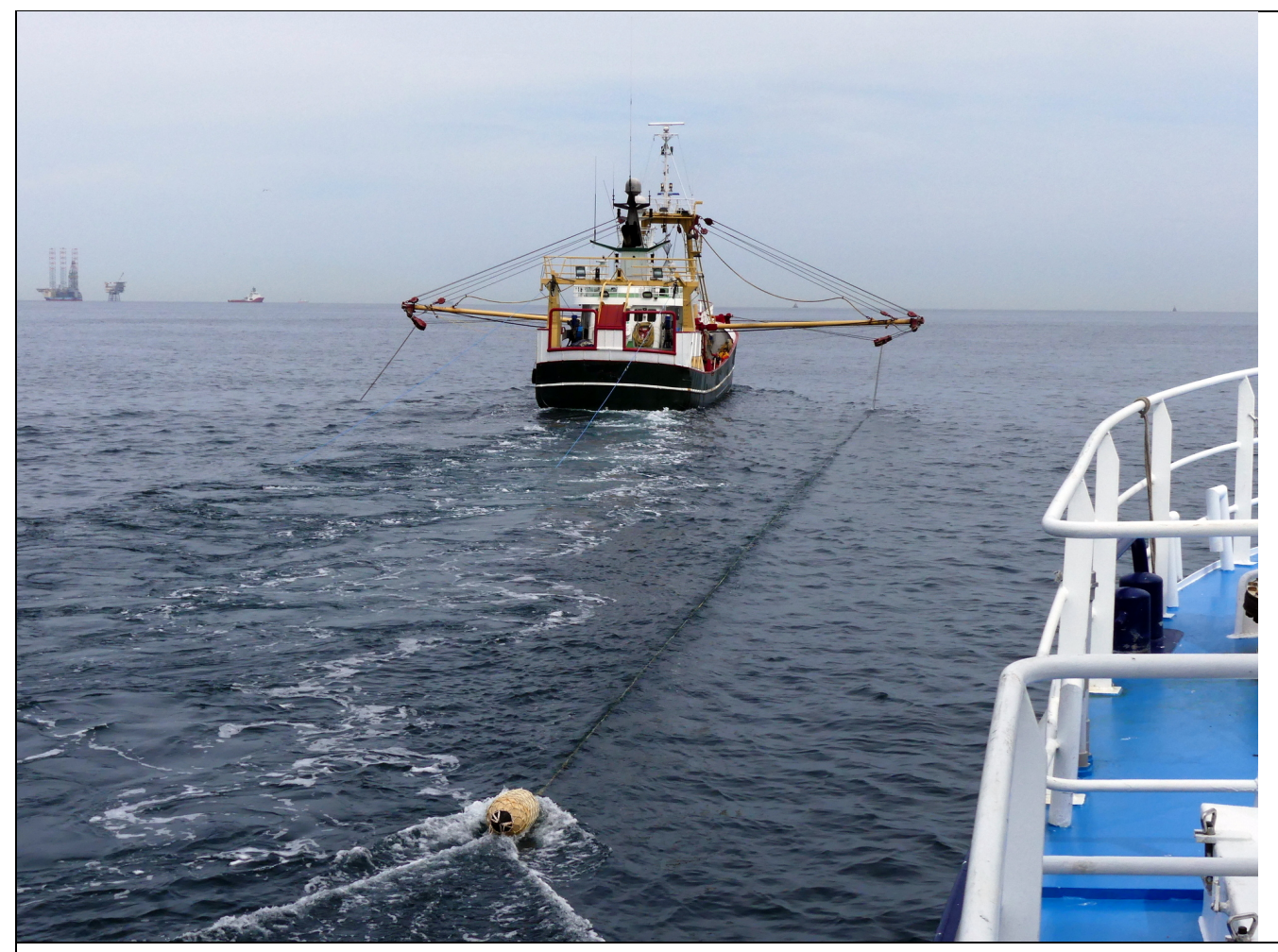

Photo 1: A buoy on a $100 \mathrm{~m}$ rope attached to the end of the boom of the pulse trawler aided to maintain the shrimp trawler in proper position. (Photo by Edward Schram)

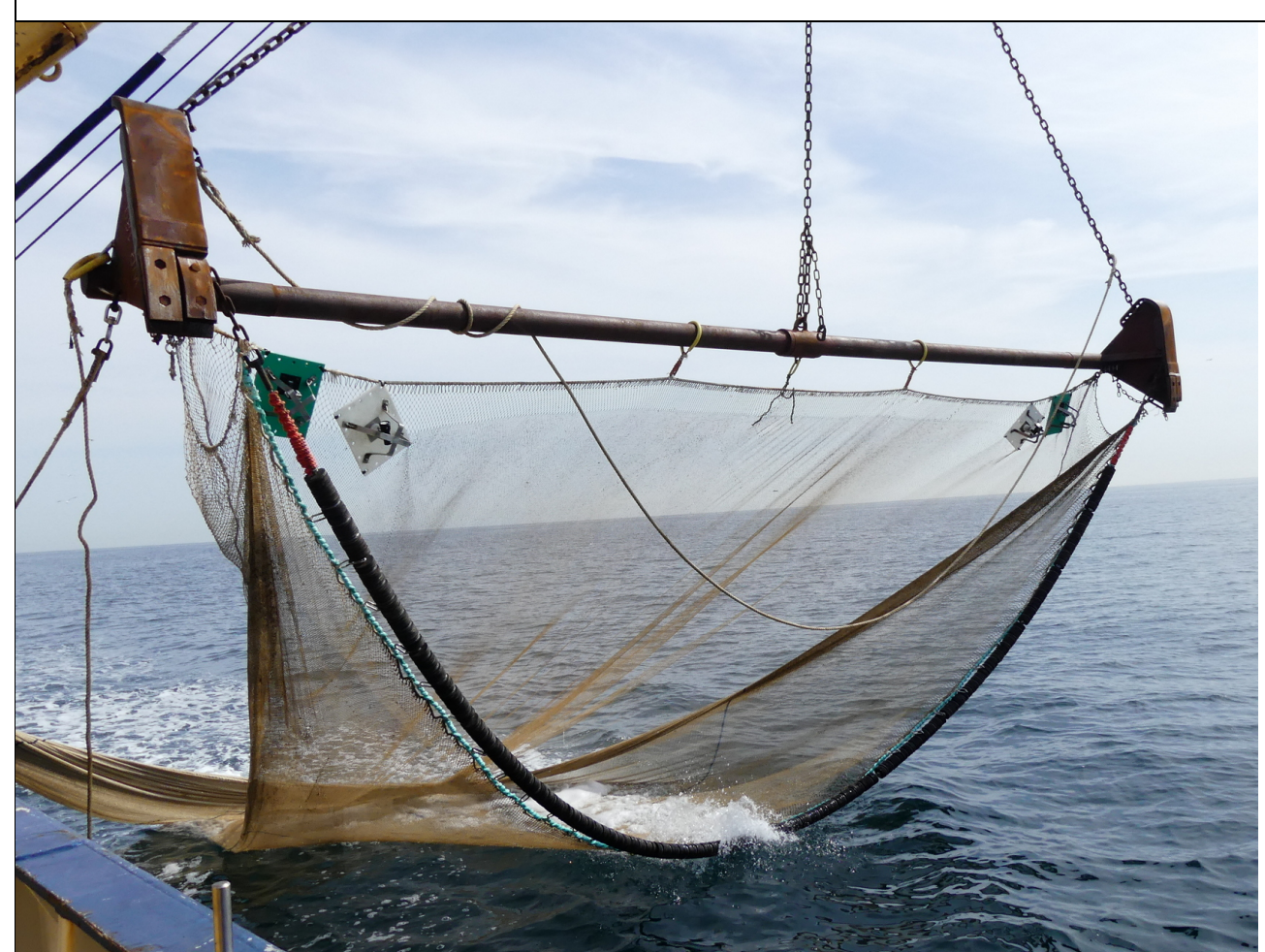

Photo 2: The shrimp trawl deployed in a pulse track was equipped with two (GOPRO) cameras and lights to obtain visual confirmation of sampling inside the pulse track. The conventional bobbin ground ropes of the commercial shrimp trawls were replaced by heavy closed ground ropes consisting of rubber discs supplemented with 97 additional lead discs. (Photo by Edward Schram) 


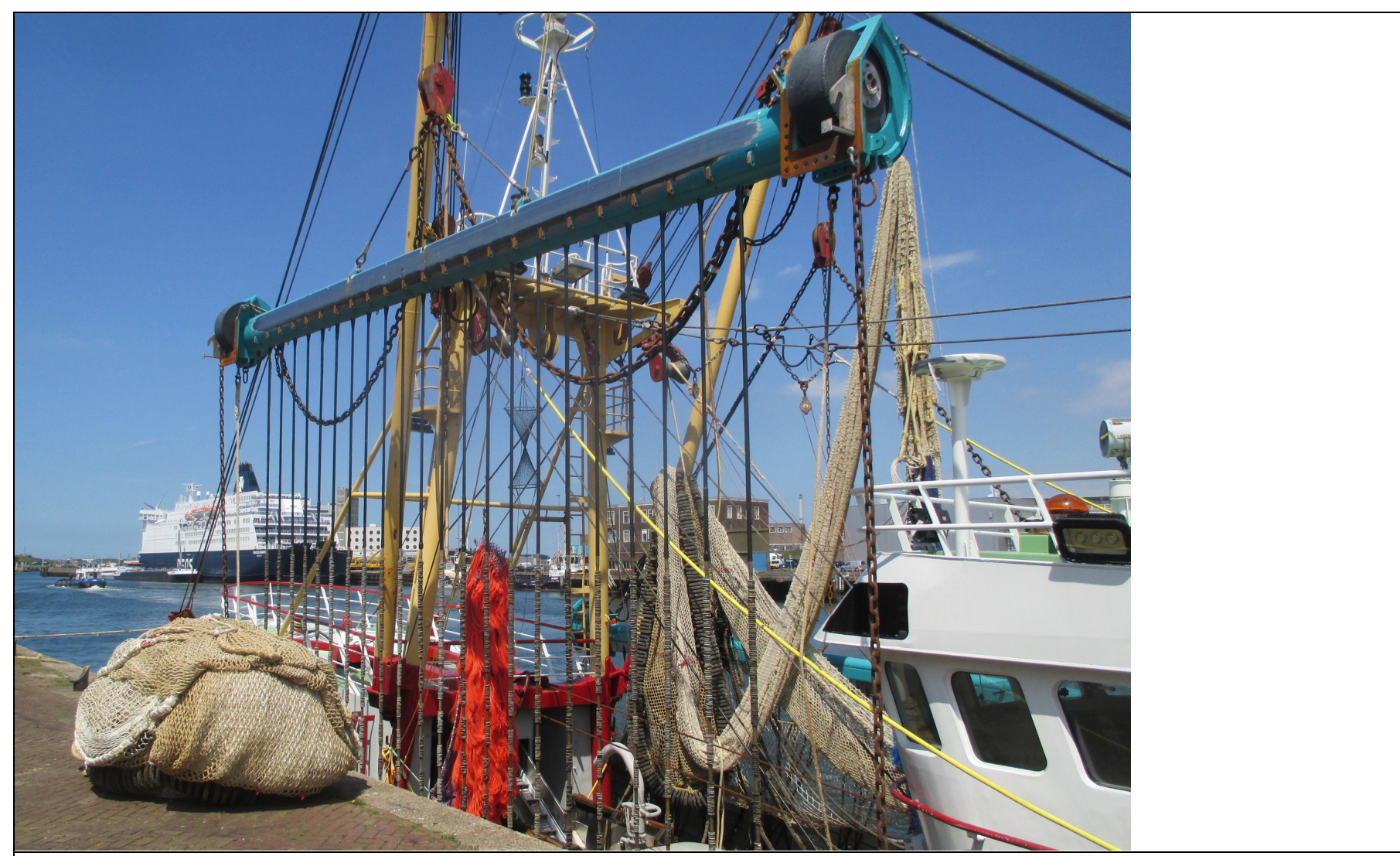

Photo 3: Both pulse trawls had chains $(10 \mathrm{~m}, \emptyset 18 \mathrm{~mm}$ ) attached to each end of both seawings to create clearly visible slits on the seafloor that mark the boundaries of the pulse trawl tracks. (Photo by Pieke Molenaar)

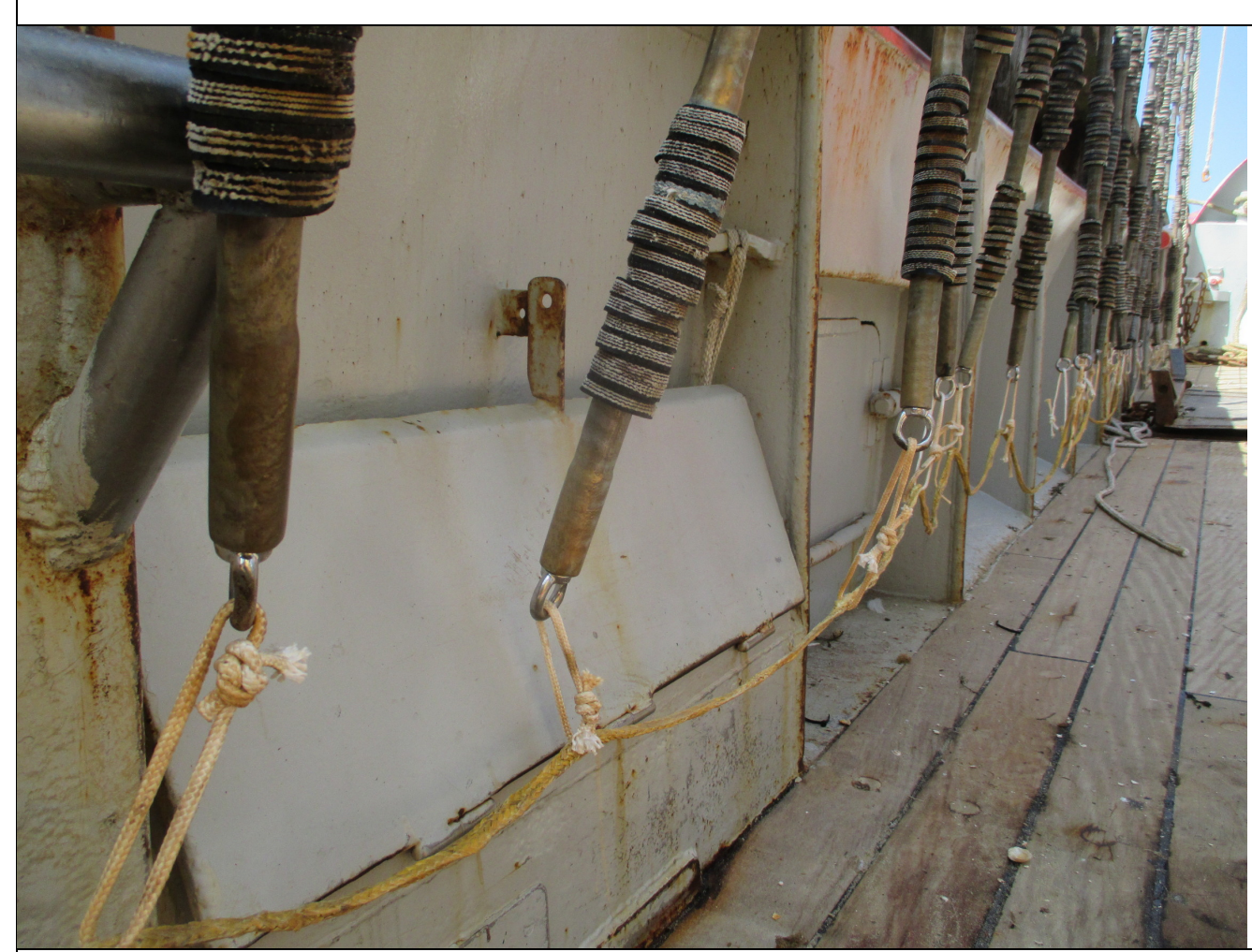

Photo 4: The electrodes of the pulse trawl without footrope and net were fixed in parallel position by ropes between the aft ends of adjacent electrodes. (Photo by Pieke Molenaar) 


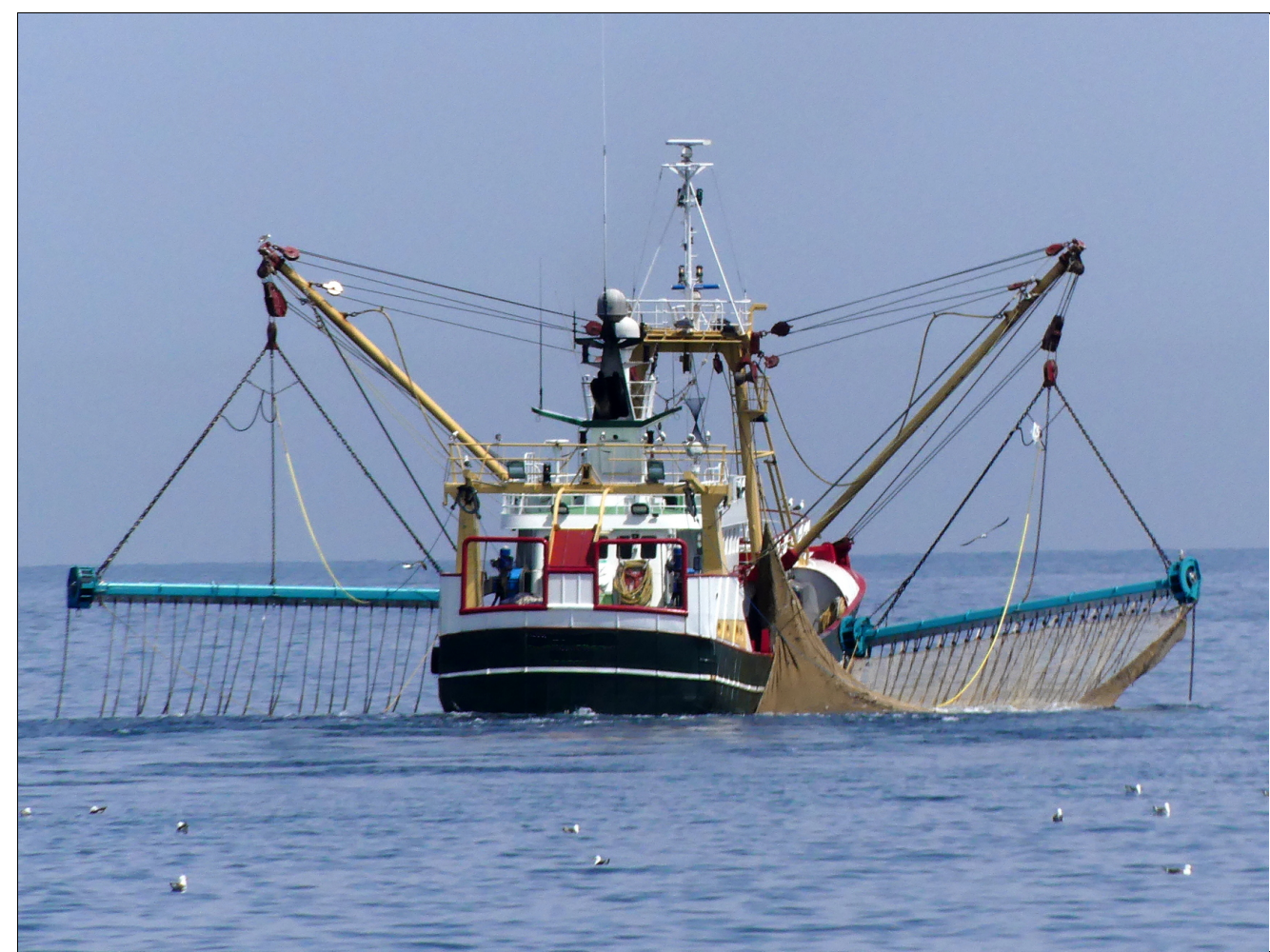

Photo 5: The experiment consisted of two treatments, a pulse trawl track by a complete pulse trawl (treatment PULSE_CMPLT, starboard trawl) and a pulse trawl track by a pulse trawl with its netting and ground rope removed (treatment PULSE_NO NET, port side trawl). (Photo by Edward Schram)

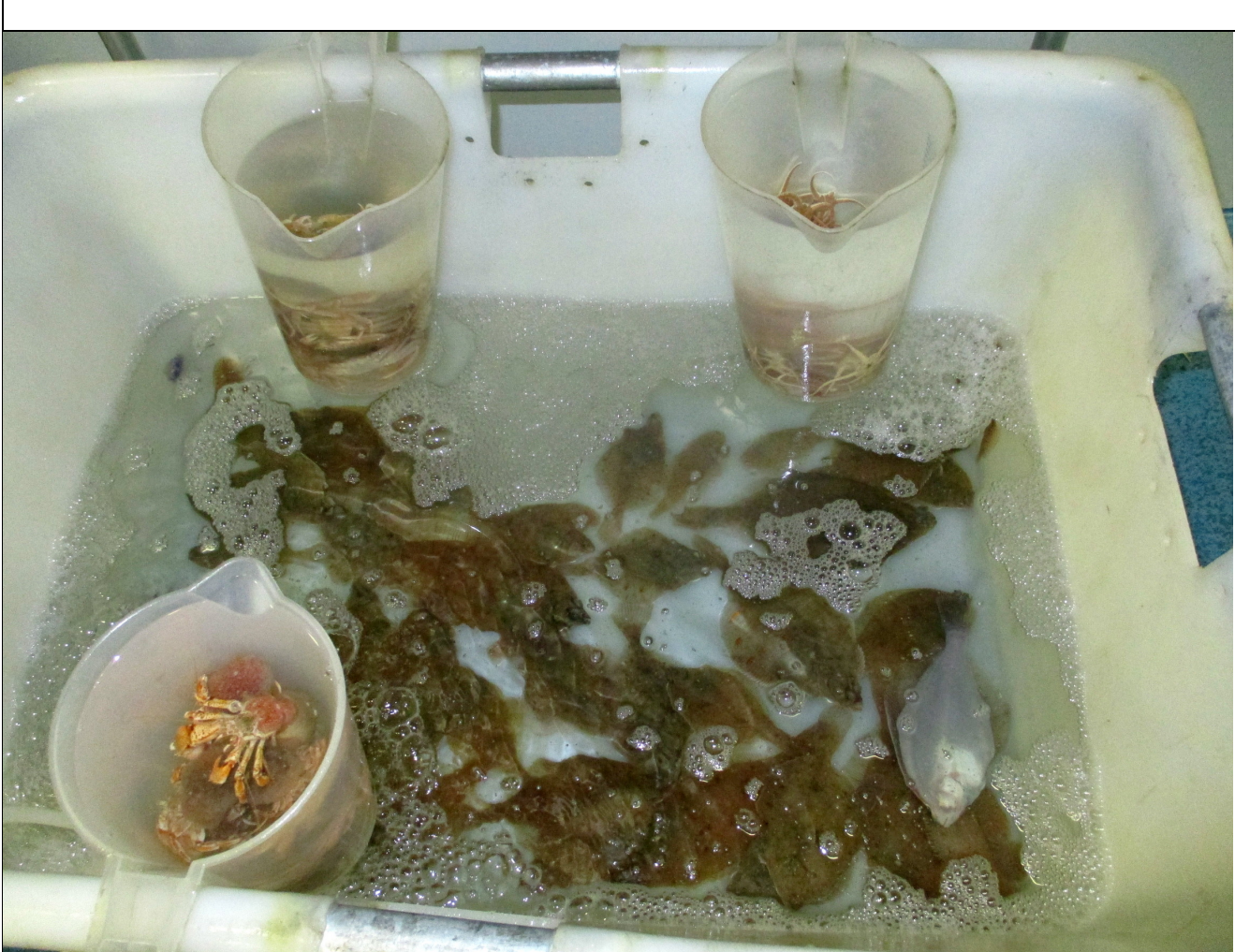

Photo 6: Per sample all sub-sampled fish were placed in a single $105 \mathrm{~L}$ container filled with aerated seawater (Photo 6, Annex 2). For the invertebrate species we used separate containers per species. (Photo by Pieke Molenaar) 


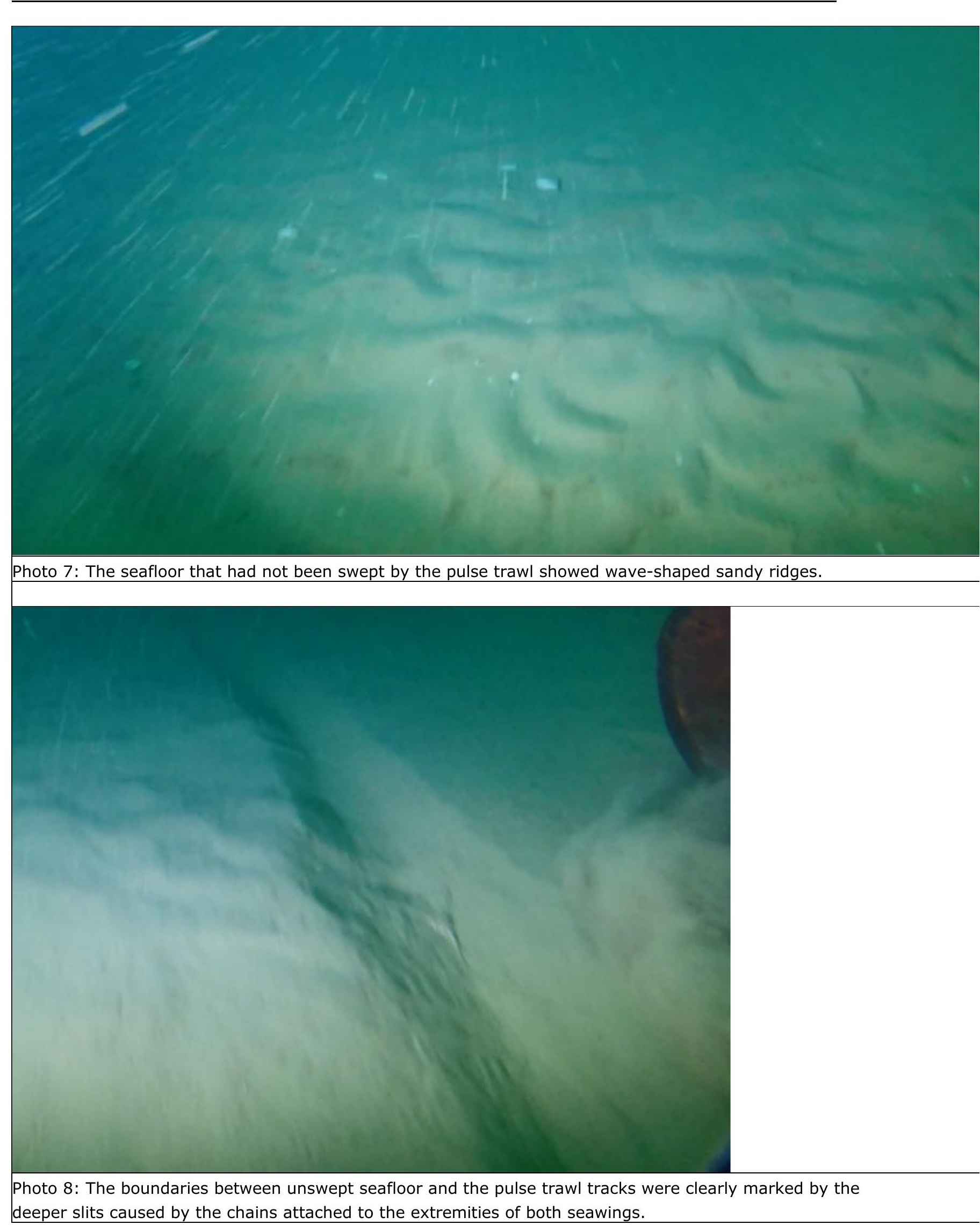




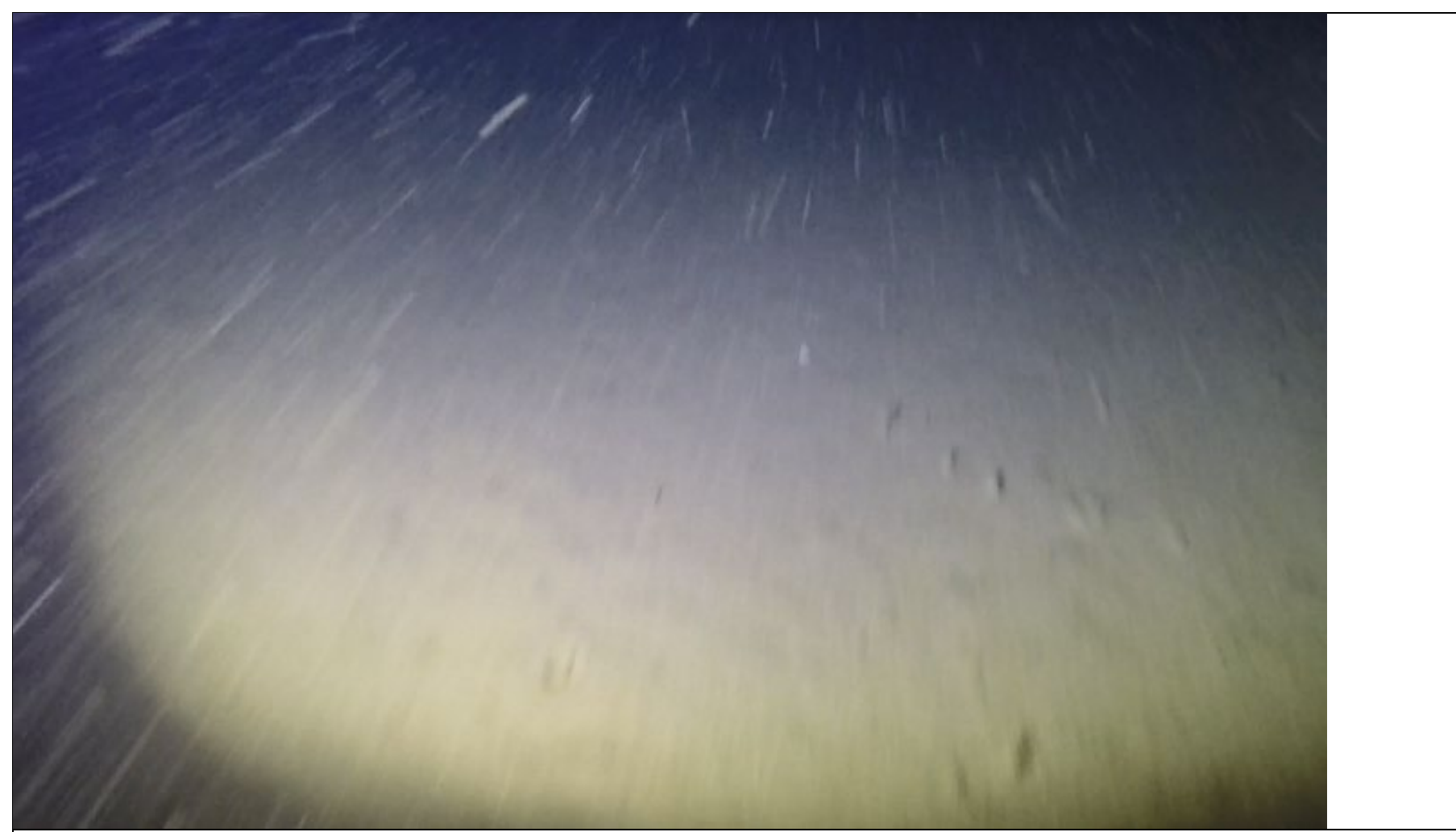

Photo 9: Inside the track made by the complete pulse trawl, with net and ground rope, the sandy seafloor had been smoothed out; the wave-shaped sandy ridges had disappeared.

Photo 10: Inside the track made by the pulse trawl without net and ground rope, parallel slits drawn by the pulse modules were clearly visible in the sand. 


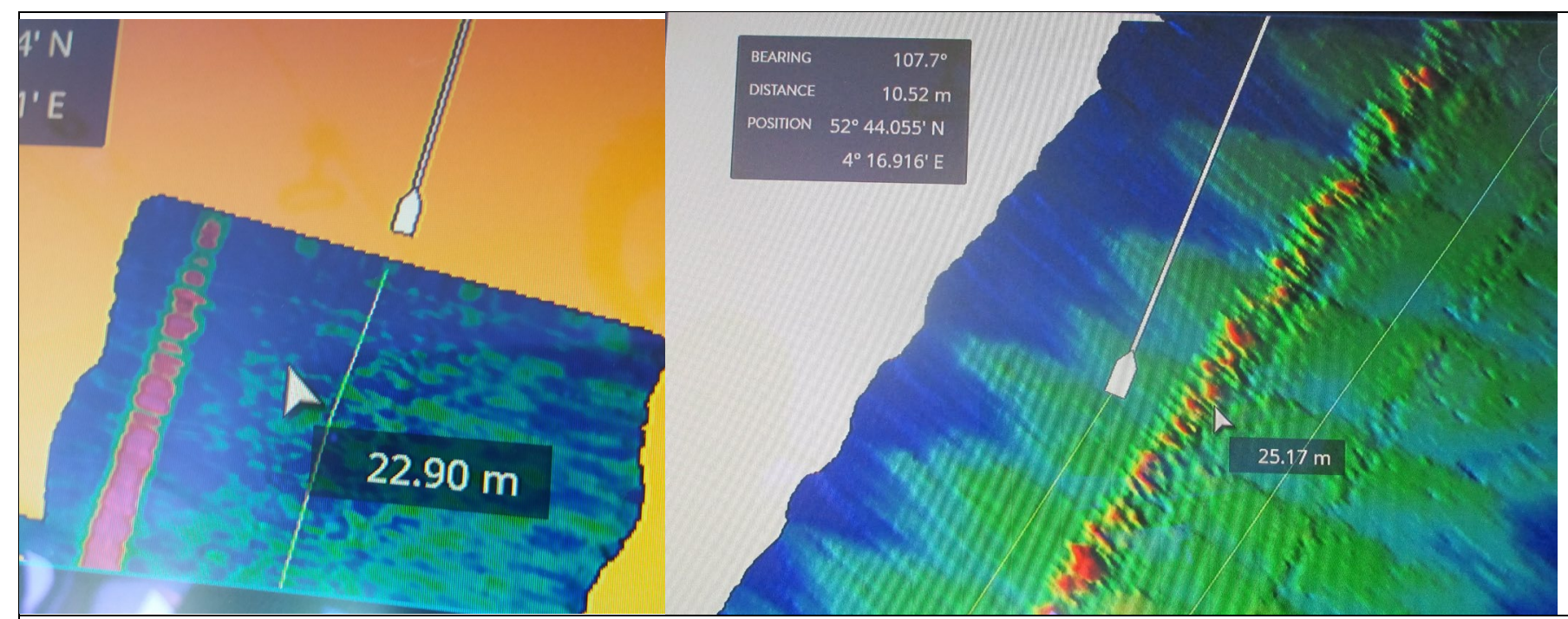

Photo 11: Left. WASSP image of the pulse trawl with net (red colour) when shrimp trawler was positioned above the pulse trawl while tracking the pulse trawler. Right. Experimental tow after tracking with starboard shrimp trawl in the pulse trawl track. 
Wageningen Marine Research

$\mathrm{T}+31(0) 317480900$

E: marine-research@wur.nl

www.wur.eu/marine-research

Visitors' address

- Ankerpark 271781 AG Den Helder

- Korringaweg 7, 4401 NT Yerseke

- Haringkade 1, 1976 CP IJmuiden
With knowledge, independent scientific research and advice, Wageningen Marine Research substantially contributes to more sustainable and more careful management, use and protection of natural riches in marine, coastal and freshwater areas.
Wageningen Marine Research is part of Wageningen University \& Research. Wageningen University \& Research is the collaboration between Wageningen University and the Wageningen Research Foundation and its mission is: 'To explore the potential for improving the quality of life' 